\title{
LAND-COVER CHANGE IN THE DEPARTMENT OF VICHADA, COLOMBIA, FROM 1985 TO 2017
}

\author{
CAMBIO DE USO DEL SUELO EN EL DEPARTAMENTO DEL VICHADA, \\ COLOMBIA, DESDE 1985 A 2017
}

\begin{abstract}
Juan J. Vitar-Mendoza•juan.vitar@unillanos.edu.co* Biologist, SUSA investigation group, Department of Biology and Chemistry, Faculty of Basic Science and Engineering, University of the Llanos, Villavicencio, Colombia.
\end{abstract}

Karen X. Sandoval-Parra • Karen.sandoval@unillanos.edu.co, MSc. Molecular, Cellular and Genetic Biology, SUSA investigation group, Department of Biology and Chemistry, Faculty of Basic Science and Engineering, University of the Llanos, Villavicencio, Colombia.

Martha L. Ortiz-Moreno•mlortiz@unillanos.edu.co Doctor in Ecology and Natural Resources, Department of Biology and Chemistry, Faculty of Basic Science and Engineering, University of the Llanos, Villavicencio, Colombia.

*Corresponding author

Citación: Vitar-Mendoza, J., Sandoval-Parra, K., Ortiz-Moreno, M. (2022). Land-cover change in the department of Vichada, Colombia, from 1985 to 2017. Revista de Investigación Agraria y Ambiental, 13(1), 149 - 174. DOI: https://doi.org/10.22490/21456453.4630

\section{ABSTRACT}

Contextualization: Colombia has experienced multiple land-cover changes derived from socio-economic policies that have reduced the high biodiversity of the country.

Knowledge gap: In the Orinoquía region, the pressure to expand the agricultural frontier is increasing, without considering the importance of its natural resources.

Purpose: This paper aimed to analyze the land-cover variations associated with agricultural practices, in the department of Vichada, with a special interest in vulnerable ecosystems, such as the Bita's river basin, using Geographic Information System [GIS] analysis of historical images taken by a remote sensor from the United States Geological Service [USGS] Earth Explorer portal.

Methodology: Documental review and an analysis of satellite images from 1985 to 2017.
Results and conclusions: The results showed that in Vichada, during a 32-year period, there was a transition from forest to cropland and pastures, in which $60 \%$ of the forest cover got lost. Moreover, areas of natural savannas were also replaced with pastures for livestock production. These land-cover changes were associated with government policies that fomented illegal occupation of land, monocultures, and nonnative plantation forests. Bita's river basin also lost a significant part of forest cover because of agribusiness development in the municipality of Puerto Carreño (Vichada). These land-cover changes have an impact on the ecological integrity of significant ecosystems and in their functionality in the region, that is why, conservation measures must be implemented.

Keywords: Agribusiness; Agricultural frontier; Biodiversity; Deforestation; Satellite imagery analysis 


\section{RESUMEN}

Contextualización: Colombia ha experimentado múltiples cambios en la cobertura de los suelos como consecuencia de políticas socioeconómicas, reduciendo, de esta forma, la alta biodiversidad del país.

Vacío de investigación: En la región de la Orinoquía se han intensificado las presiones para ampliar la frontera agrícola, sin considerar la importancia de sus recursos naturales.

Propósito del estudio: Este trabajo tuvo como objetivo analizar el cambio de cobertura asociado a las prácticas agrícolas en el departamento de Vichada, con especial interés en ecosistemas vulnerables, como la cuenca del río Bita, mediante un análisis SIG de imágenes históricas tomadas por sensores remotos del portal Earth Explorer del USGS.
Metodología: Se realizó una revisión documental y un análisis de imágenes satelitales desde 1985 a 2017.

Resultados y conclusiones: LoS resultados mostraron que en Vichada, durante un período de 32 años, hubo una transición de bosques a cultivos y pastizales en el que se perdió el $60 \%$ de la cobertura forestal. Además, las áreas de sabanas naturales también fueron reemplazadas por pastizales para la producción ganadera. Estos cambios en la cobertura del suelo se asociaron con políticas gubernamentales que fomentaron la ocupación ilegal de tierras, los monocultivos y las plantaciones forestales de especies no nativas. La cuenca del río Bita también perdió una parte significativa de su cubierta forestal, como consecuencia de los agronegocios.

Palabras clave: Agronegocios; frontera agrícola; Biodiversidad; Deforestación: Análisis de imágenes satelitales 


\section{GRAPHIC SUMMARY}

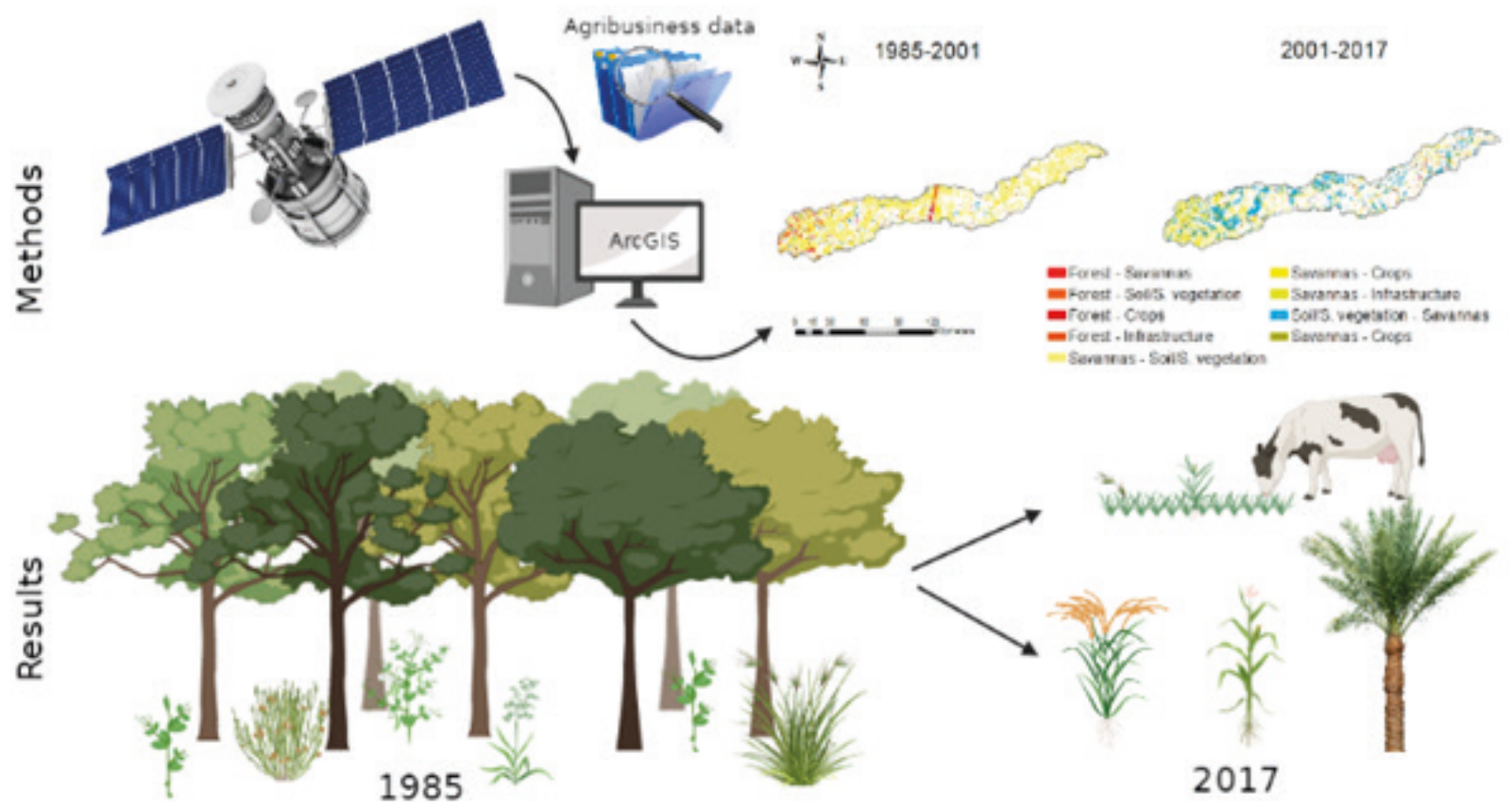

\section{INTRODUCTION}

Biodiversity is one of the most important components of the planet. It comprises the entire variety of living organisms from all environments and their ecological complexes, including genetic, structural, and functional components (Newbold et al., 2015). In the last decades, biodiversity has been negatively impacted by anthropogenic activities, causing the alteration of ecosystems and the services that they provide (Caviedes and Ibarra, 2017).

Over the last fifty years, the main causes of the damages to ecosystems integrity are variations in land-cover and in land-use (Allan et al., 2015; Jantz et al., 2015; Newbold et al., 2015). Land-use changes have suffered a transition, from natural vegetation to clearings, so land can be used for small-scale agriculture, croplands, livestock production, infrastructure and urban development, mining, and others (Boserup, 2017; Rausch, 2017). The deforestation and forest fragmentation resulting from these transitions have important effects on the landscape, such as the reduction of forest quality, isolated patches, edge effect and connectivity loss. All together lead to disruptions in the functional structure of biological communities (Brodie et al., 2015; Hurd et al., 2016; Thompson et al., 2017).
In Latin America, socio-economic factors and biophysical parameters of landscape represent the main causes of land-use changes (Borras et al., 2012; Rausch, 2017). Two highly used approach to study these changes are: satellite-derived data, and monitoring strategies, such as the Normalized Difference Vegetation Index [NDVI] (Addabbo et al., 2016; Chakraborty et al., 2018). The NDVI allows creating an image that quantifies the photosynthetic capacity of different plant canopies (Chakraborty et al., 2018). In Colombia, this strategy has been used for research, using multitemporal analysis and monitoring river basins (Álvarez \& Agredo, 2013; Vargas-Gonzalez, 2013; Grande-Medina, 2015; Mejía-Ramírez, 2016; Monroy \& Armenteras, 2017; Barragan-Vera, 2018; Sanabria-Lombana, 2018; HernándezCalderón \& Salamanca-Carvajal, 2019; Salamanca-Córdoba, 2020). An example of using NDVI comes from the work of Muñoz et al., (2009). Their results showed that in Las Minas micro-basin, municipality of Pasto (Department of Nariño), 58.51 ha were deforested between 1989 and 2008 (Muñoz et al., 2009). Another related research comes from Monroy and Armenteras, (2017), that showed the quantification of the land cover changes, and the expansion of mining 
dynamics in the Nechí river from 2009-2014 (Monroy \& Armenteras, 2017).

On the other hand, the Orinoquia region of Colombia is considered the future core of agricultural practices, creating a great deal of pressure towards resources exploitation, without contemplating the impact on biodiversity (Caicedo, 2016; PeñaLevano et al., 2018). The National Planning Department [DANE] of Colombia stated, in 2017, that agro-industrial projects and large-scale forestry are the only options to accelerate the region development. So, the development strategy for this region includes the transformation of forest into cropland, pastures for livestock, logging for energy purposes, and the construction of roads. These anthropogenic activities represent the main causes of the loss of forest worldwide (Dudley \& Alexander, 2017). Additionally, these processes are associated with social, political, and economical changes that have led to a disorganized growth of urban areas (Caicedo, 2016).

In regions such as the Orinoquía, where the loss of integral ecosystems in favor to agroindustrial expansion is expected, complete knowledge of the biodiversity represents a concern among academics, as it is necessary to develop conservation strategies that reduce the impacts on the ecosystem services, especially when essential ecosystems like river basins are compromised (Williams et al., 2020). Therefore, the aim of this study was to analyse the transformation of landcover in the department of Vichada, between 1985-2017 period, and the expansion of agribusiness, with special attention to the Bita's river basin, utilizing simple GIS analysis and data from the USGS Earth Explorer portal.

\section{MATERIALS AND METHODS}

\section{STUDY AREAS}

\section{Department of Vichada}

The Orinoquía region constitutes $30.4 \%$ of the national territory and is located in the southeast of Colombia. This region has $32 \%$ of the country fresh water and $38 \%$ of all micro-basins (Yepes-Mayorga, 2012). Hence, it is one of the most important reservoirs of biodiversity in the neotropics (Gassón, 2002) with 156 different types of ecosystems and a high number of gramine, amphibians, reptiles and mammals (Yepes-Mayorga, 2012), fishes (Maldonado-Ocampo et al., 2008; Romero et al., 2009), and bird species (Trujillo \& Lasso, 2017).

The Altillanura is the subregion of Orinoquía where the economic interest is concentrated, and $57 \%$ of 13.5 million ha are considered suitable for agriculture. The remaining area (43\%) is classified as natural forests, morichales (lotic systems dominated by Mauritia flexuosa), savannas, and semi-natural areas (Trujillo \& Lasso, 2017). The department of Vichada is located within the Altillanura, with 10024200 ha and four municipalities: La Primavera, Cumaribo, Puerto Carreño and Santa Rosalía. The potential for agriculture in Vichada is approximately of 4.5 million ha (Gómez, 2015). In Vichada, extensive and continuous savannas shape the landscape, along with gallery forests and morichales (YepesMayorga, 2012). In 1970, El Tuparro National Natural Park was created to protect the ecosystems that regulate the hydrological cycle and control floods (Caviedes \& Ibarra, 2017; Duarte, 2016).

Vichada is the second department that has the greatest extension in Colombia (Fig. 1 ). The total population is 73700 inhabitants of which $56 \%$ live in rural areas, and almost $65 \%$ of them depend on agriculture and livestock production (DANE, 2005). The economy was initially inconspicuous with small scale extractions of rubber and wood. In 1980, an economic model based on illicit crops and extensive livestock farming was implemented (Trillos, 2010). Since then, the expansion of the agricultural frontier has been the purpose of several agrarian laws and policies (Gómez, 2015). In 2002, the project "The rebirth of the high Orinoquía of Colombia" identified productive, agricultural and agroforestry alternatives that did not include native species (MADR, 2004; Viloria, 2009).

Later, the "Action Plan on Biodiversity" policy prepared the department for a new 
strategy known as agribusiness (CGR, 2014). First, the Government stimulated the agrarian colonization in Vichada by giving land titles to newcomers. Then, the land passed to foreign and national investors, leaving the local communities evicted from their territories. As a result, large areas were accumulated for agro-industrial projects (CGR, 2014). The main foreign buyers of land in the region were companies from China, Japan, Malaysia, Indonesia, and Brazil (Nieto, 2015). Lastly, in 2014, the "National Council for Economic and Social Policy 3797" was implemented, this policy invested COP 10767 million in 780000 ha of the Altillanura to develop agroindustrial projects and promote land transformation in Vichada (CONPES, 2014; DNP, 2017).

The "Master Plan for the Orinoquía", in 2016, continued the 3797 policy, again, involving the private sector and international cooperation, without considering the local communities. Moreover, in recent years, the Colombia's government peace agreement and other political and economic drivers, have brought a significant increase to agroindustrial crops and forest plantations in Vichada (Oficina del Alto Comisionado para la Paz Colombia, 2016).
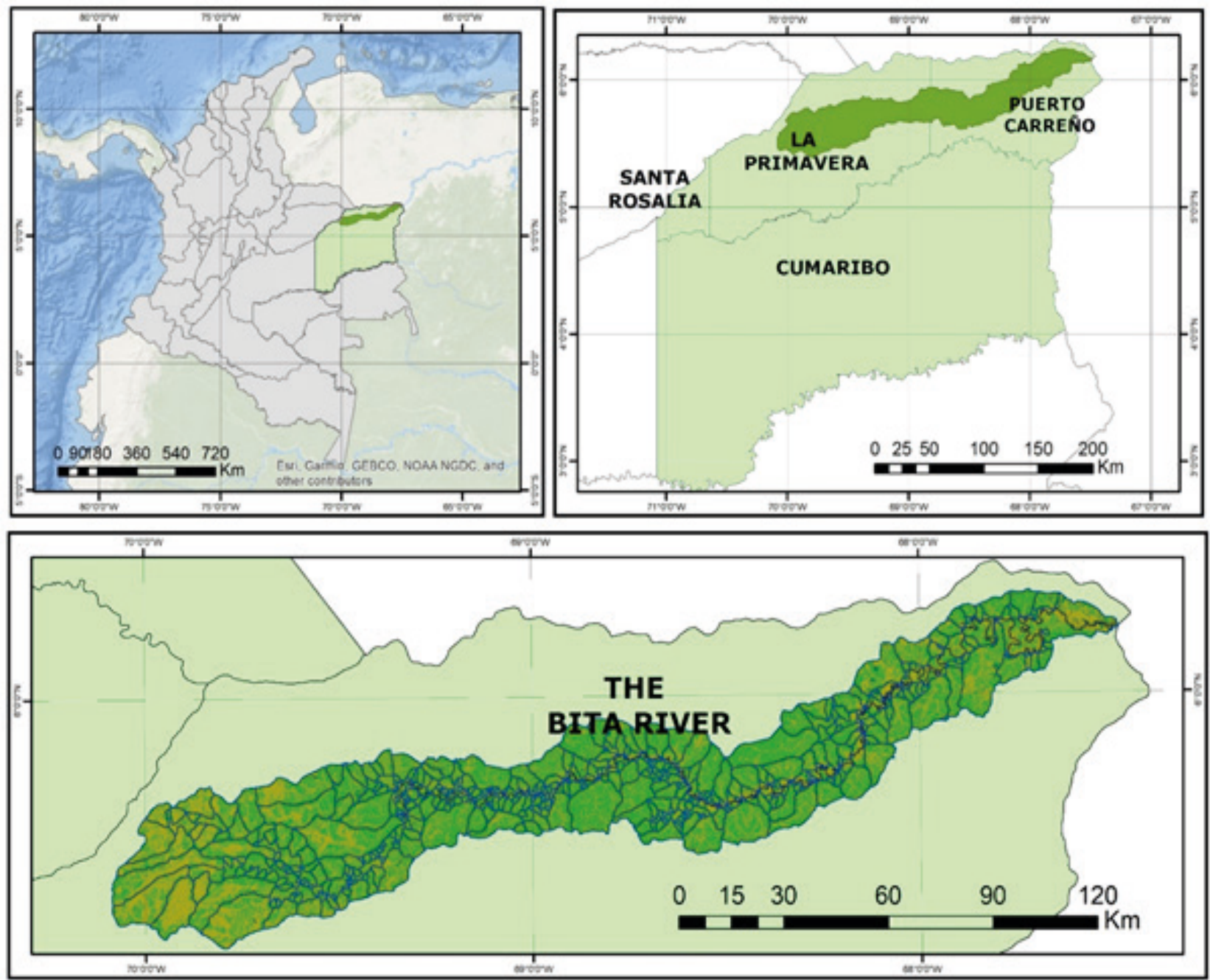

Figure 1. Location of the Vichada department and the Bita's river basin within Colombia.

Source: authors. 


\section{Bita river Basin}

The Bita river is located in Vichada, within the municipalities of La Primavera and Puerto Carreño (Fig. 1). It has a linear extension of $700 \mathrm{Km}$, an area of 812312 ha, an altitudinal gradient of 50-300 masl, an average temperature of $27-28^{\circ} \mathrm{C}$, and a monomodal precipitation regime (Peñuela \& Rodríguez, 2014; Romero et al., 2017). Gallery forests are alternated with savannas, floodplain savannas, and rocky outcrops from the Guiana Shield. There are numerous highvalue ecosystems with unique biodiversity in the basin, that include at least 16 wetlands, mainly estuaries, madreviejas (a type of permanent freshwater lagoon), zurales (a lentic and temporary water system), and morichales (Lasso et al., 2014; Romero et al., 2017).

Currently, the ecosystems in the basin have a high degree of conservation. Almost $95 \%$ of the areas are natural ecosystems, 2.5 $\%$ are agricultural or forestry territories, and $3 \%$ are semi-urban areas (Trujillo \& Lasso, 2017; Suárez et al., 2021). However, the Bita river basin is currently threatened by mining, logging, deforestation, livestock production and agricultural mega-projects in the region. These economic, social, and political interests alarmed to the scientific community. As a result, in 2018, the basin became a Ramsar's wetland, for its international importance (DNP, 2018).

Despite its importance, until today there is only one research about the biodiversity in the area. Hence, there is not enough information for the formulation of efficient conservation plans (Trujillo \& Lasso, 2017). The mentioned study was carried out in 2016, in two sections of the Bita basin (municipalities of La Primavera and Puerto Carreño) (Trujillo \& Lasso, 2017). It found 424 plant species, two species of freshwater sponges, 34 species of coprophagous beetles, 26 families of aquatic macroinvertebrates, 11 species of crustaceans, 254 species of fish, 38 species of reptiles, 18 species of amphibians, 201 species of birds and 63 species of mammals. It was concluded that the Bita river basin is important for the maintenance of migratory birds and acts as a biological corridor between the Altillanura and the Guiana Shield (Trujillo \& Lasso, 2017).
Since large scale agricultural activities in Vichada have become lucrative in the past decades, due to government incentives (Vargas et al., 2015) and, according to Castiblanco et al., (2013), these industries will expand even more, there is a need to evaluate the territory in order to determinate the landcover use and recognize the deterioration of natural areas, so resource exploitation and conservation policies can be formulated. Additionally, the impact in biodiversity have been poorly investigated in the area due to the armed conflicts that have occurred over the last 50 years in Colombia (Hoffmann et al., 2018; Romero et al., 2017). The diagram in Fig. 2 shows the overall methodology used in this study.

\section{DOCUMENTAL ANALYSIS OF AGRIBUSINESS IN VICHADA}

Several documents, regarding the development of agribusiness and the expansion of the agricultural frontier in Vichada during the period 1985-2017, were consulted as reference and comparison. Legal and administrative documents (Table 1), academic literature and press, were included as well.

\section{SATELLITE IMAGE PRE-PROCESSING}

In this study was used images acquired from the US Geological Survey Center for Earth Resources Observation and Science (USGS) (https://glovis.usgs.gov/). The dataset comprised cloud-free $(<5 \%)$ ) satellite images of the dry season (October to February), taken in the following years: 1985 and 1998, collected from the Landsat 5 satellite (TM) with a resolution of $30 \mathrm{~m}$ (USGS, 1985; USGS, 1998); 2001, 2005, 2009 and 2013, collected from Landsat 7 (ETM) with a resolution of 30m (USGS, 2001; USGS, 2005; USGS, 2009; USGS, 2013); and 2017, collected from Sentinel2 with a resolution of $10 \mathrm{~m}$ (USGS, 2017). The spatial resolution of these images made possible to identify and map agricultural fields, deforested areas, vegetated zones, and inhabited places within the landscape that were transformed during the 32 years, a methodology used in different studies that also cover large periods of time (Mendoza et al., 2011; Keshtkar et al., 2017; Ávalos et al., 2018; Souza-Filho et al., 2018). All images were georeferenced using a polynomial geometric model (order 3 ). 


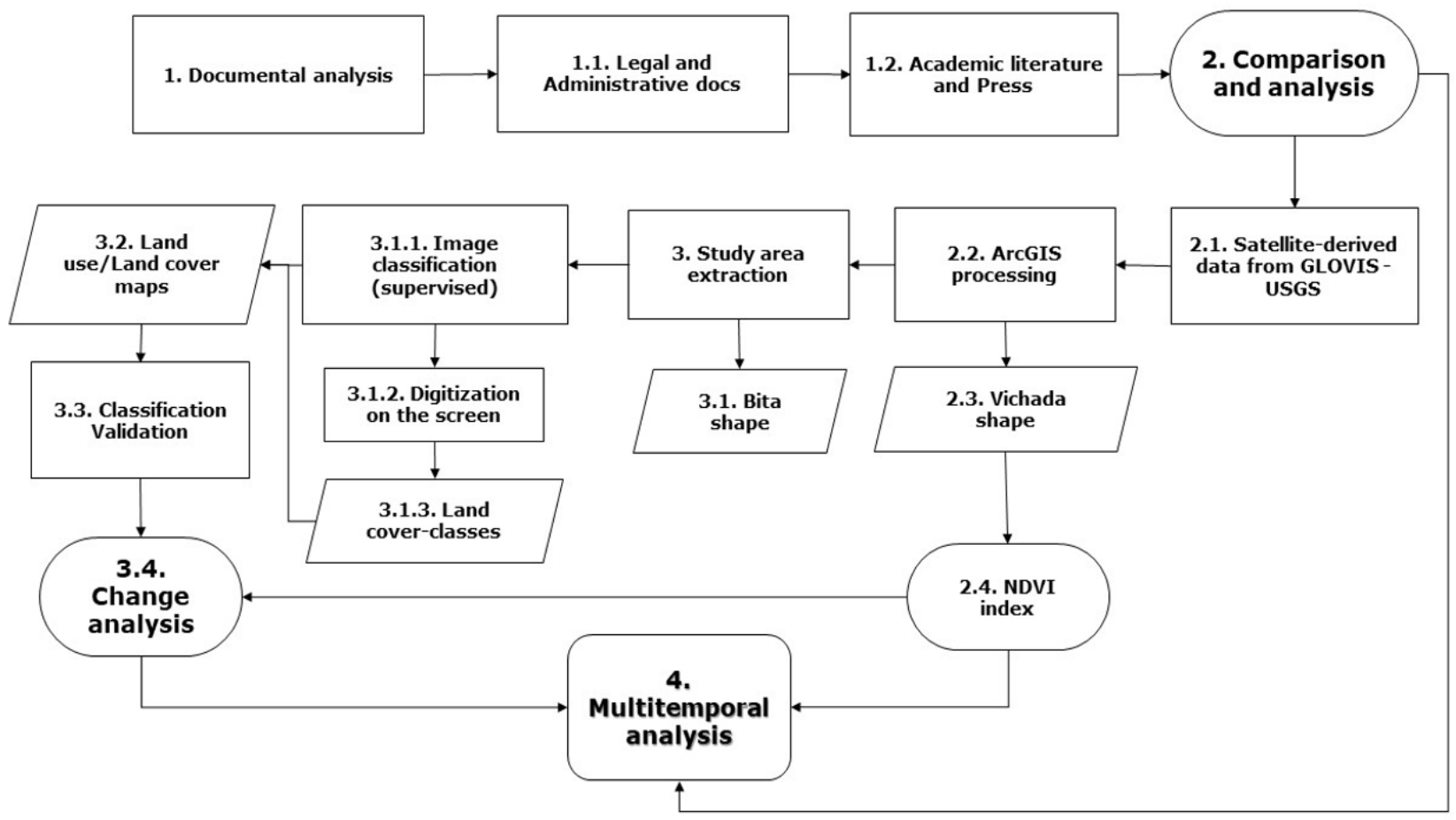

Figure 2. Schematic representation of the methodology used in the present study.

Source: Authors.

\section{DEFINITION OF THE DIFFERENT LAND- COVER CLASSES}

The satellite images were classified into seven land-cover classes (Table 2), using a pixel-based, supervised classification method, the Maximum Likelihood Classification (MLC) algorithm. MLC is one of the most widely used methods due to its quickness, userfriendly and a clear interpretation of the results (Bolstad \& Lillesand, 1991; Ávalos et al., 2018). MLC can obtain a spectral image of each land-cover class through variance and covariance statistics of the set of training sites identified in the image, and then calculates the probability of belonging to each class according to the spectral signature (Fig. 3), with accurate results (Bolstad \& Lillesand, 1991; Ávalos et al., 2018). Subsequently, a more detailed review was done digitizing the screen, especially on the land-cover near the water round.

Table 1. Administrative and legal documents consulted for the purposes of the present study.

\begin{tabular}{|c|c|c|}
\hline Type and source of document & $\begin{array}{c}\text { Revised } \\
\text { documents }\end{array}$ & References \\
\hline $\begin{array}{c}\text { Administrative } \\
\text { Ramsar-Convention on Wetlands }\end{array}$ & 2 & $\begin{array}{l}\text { Ramsar, 2015 } \\
\text { Ramsar, 2016 }\end{array}$ \\
\hline $\begin{array}{c}\text { Administrative } \\
\text { Office of the High Commissioner for } \\
\text { Peace Colombia }\end{array}$ & 1 & $\begin{array}{c}\text { Oficina del Alto Comisionado para } \\
\text { la Paz Colombia, 2016 }\end{array}$ \\
\hline $\begin{array}{c}\text { Administrative } \\
\text { Office of Ministry of Justice and Law }\end{array}$ & 1 & Minjusticia, 2014 \\
\hline $\begin{array}{c}\text { Administrative } \\
\text { Office of Ministry of Agriculture and } \\
\text { Rural Development }\end{array}$ & 2 & $\begin{array}{l}\text { MADR, 2004 } \\
\text { MADR, 2011 }\end{array}$ \\
\hline $\begin{array}{c}\text { Administrative } \\
\text { Office of Comptroller General of the } \\
\text { Republic }\end{array}$ & 2 & $\begin{array}{c}\text { CGR, 2012 } \\
\text { CGR, 2014 }\end{array}$ \\
\hline
\end{tabular}




\begin{tabular}{|c|c|c|}
\hline Type and source of document & $\begin{array}{l}\text { Revised } \\
\text { documents }\end{array}$ & References \\
\hline $\begin{array}{c}\text { Administrative } \\
\text { Colombian Federation of cattle ranchers }\end{array}$ & 1 & Fedegan, 2021 \\
\hline $\begin{array}{c}\text { Administrative } \\
\text { Office of National Department of } \\
\text { Planning }\end{array}$ & 2 & $\begin{array}{l}\text { DNP, } 2017 \\
\text { DNP, } 2018\end{array}$ \\
\hline $\begin{array}{c}\text { Administrative } \\
\text { National Administrative Department of } \\
\text { Statistics }\end{array}$ & 3 & $\begin{array}{l}\text { DANE, } 1985 \\
\text { DANE, } 1993 \\
\text { DANE, } 2005 \\
\end{array}$ \\
\hline $\begin{array}{c}\text { Administrative } \\
\text { National Council for Economic and Social } \\
\text { Policy }\end{array}$ & 7 & $\begin{array}{l}\text { CONPES 3192, } 2002 \\
\text { CONPES 3218, } 2003 \\
\text { CONPES 3467, } 2007 \\
\text { CONPES 3558, } 2008 \\
\text { CONPES 3669, } 2010 \\
\text { CONPES 3797, } 2014 \\
\text { CONPES 3827, } 2015\end{array}$ \\
\hline $\begin{array}{c}\text { Administrative } \\
\text { CIAT- Corporation for the Sustainable } \\
\text { Development of La Macarena Special } \\
\text { Management Area }\end{array}$ & 1 & CIAT and CORMACARENA, 2017 \\
\hline $\begin{array}{c}\text { Administrative } \\
\text { Orinoquía Regional Autonomous } \\
\text { Corporation }\end{array}$ & 1 & $\begin{array}{l}\text { CORPORINOQUIA, } 2009 \\
\text { CORPORINOQUIA, 2013a } \\
\text { CORPORINOQUIA, 2013b }\end{array}$ \\
\hline $\begin{array}{l}\text { Legal } \\
\text { Presidency of the Republic }\end{array}$ & 2 & $\begin{array}{l}\text { Decree 2858, } 1981 \\
\text { Decree 1729, } 2002\end{array}$ \\
\hline $\begin{array}{l}\text { Legal } \\
\text { Congress of the republic }\end{array}$ & 5 & $\begin{array}{l}\text { Law } 135,1961 \\
\text { Law 30, } 1988 \\
\text { Law 160, } 1994 \\
\text { Law } 1337,2010 \\
\text { Law } 1776,2016 \\
\end{array}$ \\
\hline $\begin{array}{c}\text { Legal } \\
\text { Office of Ministry of Agriculture }\end{array}$ & 1 & Decree 1541,1978 \\
\hline $\begin{array}{l}\text { Legal } \\
\text { Office of Ministry of Environment and } \\
\text { Sustainable Development }\end{array}$ & 6 & $\begin{array}{c}\text { Decree 3100, 2003; Decree } \\
\text { 1640, 2012; Decree 1235, 2018; } \\
\text { Resolution 157, 2004; Resolution } \\
\text { 196, } 2006 \\
\text { Resolution 1128, } 2006\end{array}$ \\
\hline $\begin{array}{c}\text { Legal } \\
\text { Orinoquía Regional Autonomous } \\
\text { Corporation }\end{array}$ & 3 & $\begin{array}{l}\text { Resolution 200.41-09-1592, } 2009 \\
\text { Resolution 200.41-11-1130, } 2011 \\
\text { Resolution 500.41-13-1571, } 2013\end{array}$ \\
\hline
\end{tabular}

Source: authors. 
The land-cover classes were adapted from the book: Leyenda nacional de coberturas de la tierra. Metodología CORINE Land Cover adaptada para Colombia Escala 1:100000 (IDEAM, 2010). The classes were chosen because the spatial resolution for all the images allowed their identification. The details of the seven land-cover classes are described in Table 2. The satellite-image matrices were easily classified using visual interpretation, considering the seven predefined classes, then using used manual vectorization via ArcGIS 10.6 software. This methodology ensured that the lines of polygons, without land-use changes, remained unaffected. The visual interpretation is a reliable method for studying small (Bita river) and large areas (Vichada) (Munsi et al., 2010; Zuo et al., 2014).

Table 2. Descriptions of seven land-cover classes identify for this study adapted from the Leyenda nacional de coberturas de la tierra. Metodología CORINE Land Cover adapted for Colombia, scale 1:100.000.

Land-cover class

Forest

Gallery forest

Cropland

Savannas

Soil / Scattered vegetation

Water

Infrastructure

\section{Description}

Natural land constituted mainly by arboreal elements of native species.

All land constituted by arboreal vegetation that forms as corridors along rivers or wetlands.

Land dedicated to permanent crops, transitory, grazing land, and heterogeneous agricultural land.

Areas constituted by a vegetal community dominated by herbaceous elements.

Areas where the ground surface consists of layers of exposed rocks and/or a slight development of vegetation such as pastures for livestock farming.

Natural streams of freshwater flowing continuously and water surface reservoirs, open or closed, which may or may not be connected with a river.

Cities, towns, areas covered by roads, highways, bridges, and airports.

Source: Authors. 


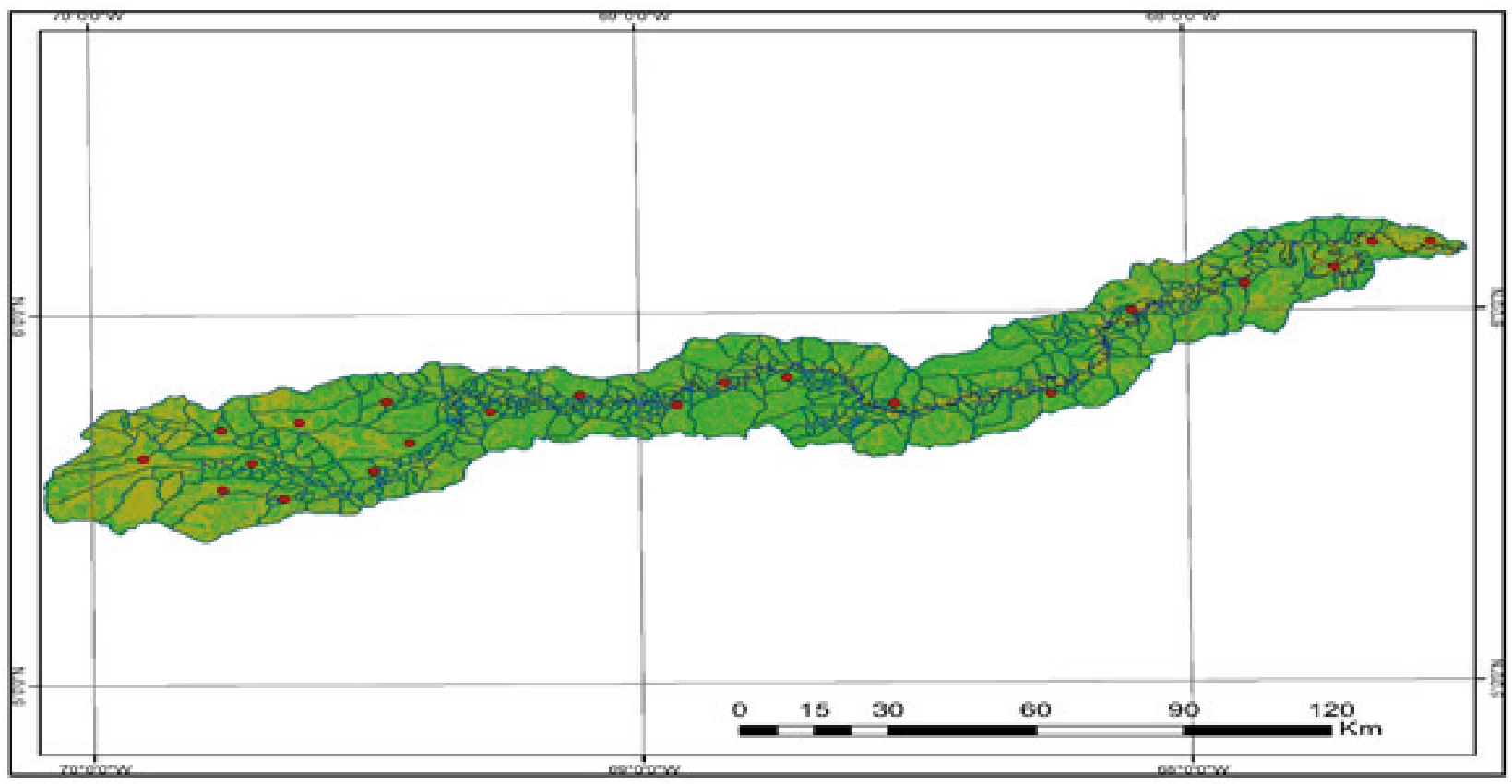

Figure 3. Location to the control fields within the Rio Bita basin.

Source: Authors.

\section{NDVI INDEX}

The NDVI index is one of the most used vegetation indices and it provides the best results regarding variations in vegetation canopies (Khan et al., 2014; Addabbo et al., 2016; Beisel et al., 2018; Sun et al., 2018). The values of the index were generated using ArcGIS by combining near-infrared bands and visible bands according to the satellite from which the images were obtained. The used formula was:

$$
\text { NDVI }=\frac{(\text { NIR-R })}{(\text { NIR }+R)} \quad(\text { Formula } 1)
$$

Where NIR $=$ Near Infrared Channel; $\mathrm{R}=$ Red Channel

The NDVI index of 10000 pixels belonging to the same land-cover class were averaged to obtain one single value. This was done for each land-cover class. Layer stack images from 1985, 1998, 2001, 2005, 2009, 2013, and 2017, were created and evaluated to detect the land-use change.

\section{MULTI-TEMPORAL ANALYSIS OF LAND- COVER CHANGE}

Land-cover maps were designed in the methodological framework of a multi- temporal analysis to evaluate the land-cover changes in a 32-year period. ArcGIS and satellite images of the Bita river basin of the years 1985, 2001 and 2017 were used. The different bands from the satellite imagery were combined in the traditional RGB (Red, Green, and Blue) channels (Fröhlich et al., 2013; Sheng et al., 2020). The combination 742 was used for the images obtained from Landsat 5 and 7; and 843 for those obtained from Sentinel-2; those band composites correspond to false colour and false IR colour respectively (Nawar et al., 2014; Príncipe \& Willems, 2018; Modica et al., 2019). This combination is suitable for studies involving natural vegetation and cropland (Addabo et al., 2016; Chakraborty et al., 2018). Based on the obtained images, polygons for each land cover class were created and the area in hectares was calculated using ArcGIS tools in the two evaluated periods: 1985 to 2001, and 2001 to 2017. Deforestation rates were not estimated in this study.

Based on the land-cover maps obtained, two processes were carried out: a majority filtering procedure (6x6 pixels) and a method of generalization of polygons of less than one hectare, thus, reducing image noise and isolated polygons. After these, the final land-cover maps were obtained, one for the period 1985-2001 and one for 2001-2017 
(Fig. 6-Annex). Polygons for each land-cover class were created and their area calculated in hectares using MLC. To standardize and confirm the land-cover areas of the Bita river basin, a visual inspection using secondary information and historical data from the IGAC web portal (https://geoportal.igac.gov.co/) and geoviewers was performed for the same analyzed periods. To obtain percentages of each land-cover class in the evaluated year (1985, 2001 and 2017), the total area of the Bita river basin, 812310 ha, was considered; each land-cover class area (in ha) was multiplied by $100 \%$ and then divided by 812310 ha.

To validate the obtained results, the classified land-cover maps were compared against control fields through a crosstabulation matrix. The kappa index (which indicates the degree of similarity between control fields and the maps), the general accuracy (which shows the percentage of pixels correctly classified), the user's accuracy (that provides the percentage of each land-cover class that corresponds with the field information) and the producer's accuracy (that establishes the percentage of each land-cover change properly classified in the image) were evaluated (Ávalos et al., 2018; Wu et al., 2018).

\section{RESULTS AND DISCUSSION}

Land change is the result of a complex interaction between multiple factors, such as economy, demography and environment, at different spatial-temporal scales. Since land-cover change can be a rapid process, understanding its relationship with driving factors is vital to evaluate the effect of land transitions in ecosystems (SantacruzDelgado, 2019). In the particular case of the department of Vichada, these processes are related to the socioeconomic status of the Altillanura region, an isolated region with high levels of poverty, institutional absence, and grave human rights violations (OXFAM, 2013).

\section{DOCUMENTAL ANALYSIS OF AGRIBUSINESS IN VICHADA}

Three main processes acted as driving factors of land change in Vichada: first, a large number of land transactions; second, the arrival of investors and multinationals and third, the current agro-industrial dynamics (CONPES, 2014). As a result, the land was occupied by foreign and national investors, who accumulated large areas of land without the proper regulation of any local or regional authorities and taking advantage of the abolition of the Law 160 (Agrarian Reform) that limited the area that could be purchased, in favor of the Law 1776 of 2016 that created the ZIDRES (Areas of Interest for Rural, Economic and Social Development), which supported only great agro-industrial projects (Aide et al., 2013; Etter et al., 2008; Ortega, 2016).

Considering those facts, this paper presents the first regional land-cover change description of the department of Vichada and the Bita's river basin. The constructed maps represent a 32-year period with intense landuse transformations.

The information regarding agribusiness in the department, during the 1985-2001 period, was non-existent, mainly because agricultural development was incipient. Oppositely, the period between 2001-2017 was characterized by agrarian and resource management policies (described in the introduction) that resulted in agricultural megaprojects occupying more than $50 \%$ of the territory in Vichada (Table 3). That included oil palm and other crops such as cashew nuts, which are perennial plants that require a wide range of time to reach productive size and be industrialized. Moreover, Colombia has recently ended a 50 years armed conflict, by signing the Peace Agreement with the militia group FARC in 2016. That agreement included policies that stimulated the economy of Vichada, having as a result a significant increase of agro-industrial crops and forest plantations (Oficina del Alto Comisionado para la Paz Colombia, 2016).

Some of the biggest agribusiness in Vichada are (CGR, 2014; Gómez, 2015; Gómez \& Soto, 2012): 
Table 3. Area and percentages of agribusiness found from 1985 until 2001, and from 2001 until 2017 in the Vichada department.

\begin{tabular}{ccccc} 
Agribusiness & \multicolumn{2}{c}{$1985-2001$} & \multicolumn{2}{c}{$2001-2017$} \\
Cereals & NIA & NIA & 96384 & $11.86 \%$ \\
Rubber & NIA & NIA & 25000 & $3.08 \%$ \\
Oil palm & NIA & NIA & 21205 & $2.61 \%$ \\
Illicit crops & 9200 & $1.13 \%$ & 2264 & $0.28 \%$ \\
Forest plantations & 8000 & $0.98 \%$ & 69762 & $8.59 \%$ \\
Other crops & 3816 & $0.47 \%$ & 38000 & $4.70 \%$ \\
Extensive livestock production & 107000 & $13.23 \%$ & 180000 & $22.25 \%$ \\
\hline & NIA: No Information Available. & & \\
\hline
\end{tabular}

Sources: CGR (2014); Gómez \& Soto (2012); Fedegan (2021); Gómez (2015); Viloria (2009).

- Cargill-Colombia Agro: started operations in Vichada in 2010, is the country's largest grain farm with over 60000 ha of wheat, soybean, rice, sorghum, and corn crops.

- Riopaila-Castilla: started operations in 2010 with 10000 ha of oil palm, 5000 ha of timber, 20000 ha of grains, and 5000 ha of technified extensive livestock production.

- Forest First: started operations in 2006 with 20000 ha of different tree species. This initiative could represent a threat to ecosystem stability considering that nonnative arboreal species were introduced.

- Indupalma: started operations in 2012 with 25000 ha for rubber extraction.

Lastly, there is an extensive livestock production, which represents about $45 \%$ of Vichada's economic activity and occupies almost a quarter of the territory (CORPORINOQUIA, 2013a; Fedegan, 2021; Viloria, 2009).

\section{VICHADA'S NDVI PROFILES AND THE INCIDENCE OF AGRIBUSINESS}

The profiles obtained in this study with the NDVI index, showed variations of the different land-cover classes during the evaluated time. The NDVI index (Fig. 4) indicates a drastic reduction of the forest cover during the 19852001 period, with a short stabilization period from 2001-2009, and then a continuous reduction until 2017. These changes are compatible with the periods of colonization and early exploitation in the territory, together with the implementation of several agrarian policies (CGR, 2014).

The index also showed that savannas and croplands remained without major variation until 2009, when they began to increase notably (Fig. 4). The savanna class includes both natural species and improved pastures introduced for livestock production. Initially, in Vichada, livestock farming was performed under the extensive system with traditional practices, which can produce a series of negative effects on the biophysical characteristics of ecosystems, such as biodiversity lost, soil compaction and erosion (Viloria, 2009). Moreover, these activities were intensified with government policies, creating monocultures of African pastures, which coincides with the increase of savannas according to the NDVI index (Table 3 ).

The review of agribusiness in Vichada showed a significant number of hectares dedicated to forest plantations (Table 3). These plantations of non-native species can alter natural ecosystems (Chakraborty et al., 2018). Although the NDVI values could be confusing about the forest plantations, and even some crops, with the natural forest cover, the forest plantation and crops can be easily distinguished in the maps by detailed observation since the plot edges are visible (Fig. 5).

Forest plantations have emerged since 2005 when government incentives were 


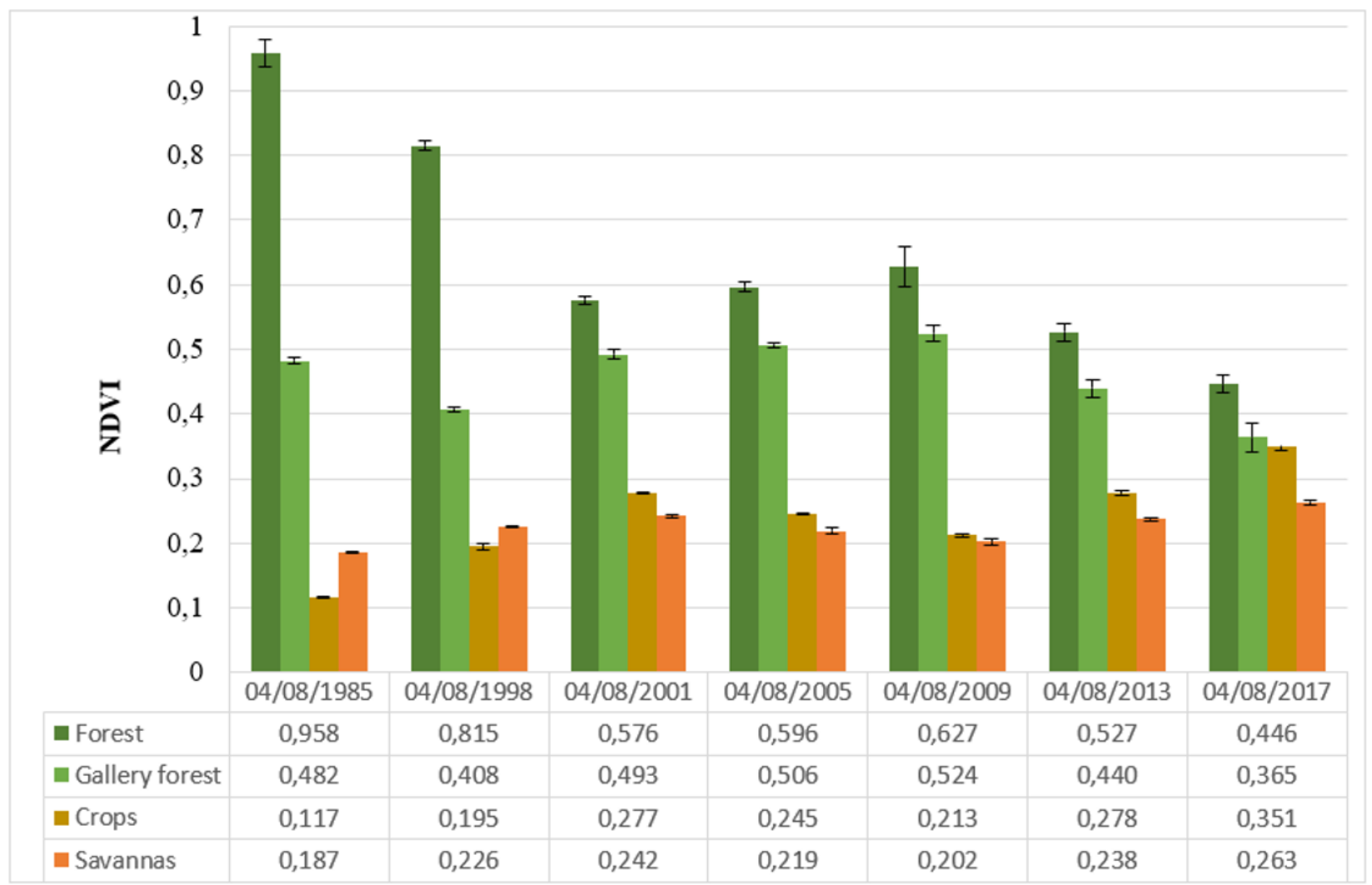

Figure 4. NDVI temporal profiles for the plant-covers in the Vichada department.

Source: authors.

implemented to promote non-native species, such as teak, tropical Caribbean pine, eucalyptus, and acacia, for timber purposes (Duarte, 2016). In 2016, almost 70000 ha of these trees were planted and about $24 \%$ of them are on the Bita's river basin (Gómez, 2015; MADR, 2004). In fact, in the present study, the transformation of natural forest into croplands and forest plantations can be observed near the basin (Fig. 5).

\section{LAND-COVER CHANGE ON A MULTI- TEMPORAL SCALE (1985-2017) IN THE BITA RIVER BASIN AND ITS RELATION WITH AGRIBUSINESS}

Table 4 lists the estimated areas for each land-cover class in the Bita's river basin, based on the analysis of satellite imagery of this study. The results showed that the forest areas decreased in the first period (from 1985 to 2001), changing from $42.84 \%$ of the total territory to $11.86 \%$, and increased in the second period (from 2001 to 2017 ) to $16.7 \%$. Overall, considering the first forest area in 1985 (347994 ha), and the last forest area in 2017 (135656 ha), there was a loss of 212338 ha, hence, $61 \%$ of the forest was lost. As a result, pastures (scattered vegetation) and croplands were increased in the first period and decreased in the second period. In both periods, savannas (natural and introduced) were increased. The savannas expanded at a higher rate in the first period and then slowed down in the second.

Regarding to that situation, Perz et al. (2005) stated that, in the 90s, the Orinoquía region suffered a deforestation rate almost three times higher than the Colombian Amazon. The destruction of native forests can be directly related to agricultural progress in the department, and to the implementation of policies that boosted economic development. This is also consistent with the results of Santacruz-Delgado, (2019), who found that annual crops and pastures increased at the expense of forests, between 2000-2015, in the high plains of the department of Vichada. Moreover, change in the forest cover caused by the increase of pastures for livestock was also found in the Amazon deforestation processes (Dávalos et al., 2014). 


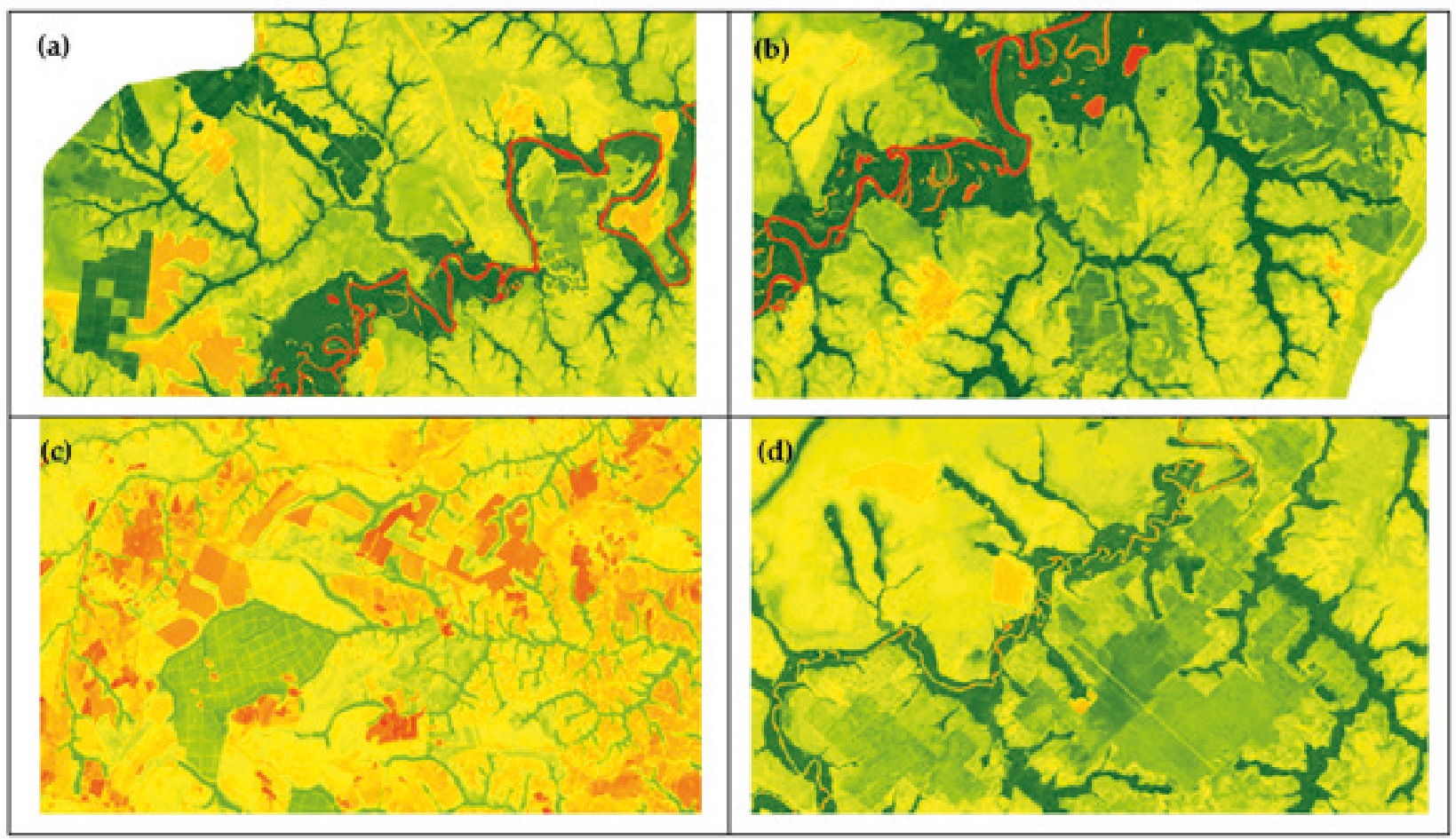

Figure 5. Zoom in NDVI layer stack images from the Bita river basin with forest plantations and monocrops (2017): (a) East area of the basin; (b) Middle part of the basin; (c) West area of the basin; (d) South area of the basin. Despite the intense green colour of forest plantations, which could be confused with natural forest, they can be easily distinguished by the plot edges.

Source: authors.

Native tropical forest areas are being rapidly transformed into mosaics dominated by pastures and agricultural matrices (Etter et al., 2005). This habitat loss has affected more ecosystems than the climate change scenarios (Newbold et al., 2015). The alteration of ecological processes due to forest lost can generate coextinctions, and hence, affect the balance and functionality of ecosystems, and the services they provide for human beings benefit (Bradshaw et al., 2008). For example, Robinson, (2018) identified in the Tumbes-Chocó-Magdalena bioregion of Ecuador, a $30 \%$ reduction of local biodiversity richness as a result of human activities and land-use changes since the 16th century. In this context, it is worth mentioning that in the Bita's river basin there are several endemic species, currently under some threat of extinction and of great biological importance, such as the plant Pepinia heliophila, the fish Pseudoplatystoma metaense, and the mammals Inia geoffrensis, Pteronura brasiliensis, Lontra Iongicaudis, Panthera onca, Puma condor and Tapirus terrestris (Trujillo \& Lasso, 2017).
Furthermore, some of the effects related to the implementation of largescale agro-industrial projects are soil degradation, disappearance of water streams, contamination by agro-toxins and biodiversity lost (Dayrell, 2012). Specifically for river basins, land-use changes result in organic matter losses, erosion, decrease in the water flow and in the availability of resources (Benstead \& Pringle, 2004; Dominati et al., 2010). Those changes have already been reported by the environmental corporation in charge of the Vichada territory, CORPORINOQUIA (Gómez, 2015). Agroindustrial processes in places with similar biophysics characteristics and land occupation dynamics as Vichada and the Bita river, such as the Cerrado region in Brazil, have resulted in drying of wetlands and selective effect in the wildlife survival (Dayrell, 2012; Ferraz et al., 2010). Therefore, the present study recommends special attention to the currently threatened ecosystems in the Bita's river basin.

Analysis of present data also showed that the forest cover had a recovery from 
88704 ha (almost $12 \%$ of the territory) to 135656 ha (almost $17 \%$ of the territory) between 2001 and 2017. However, the same consideration from the previous section should be noted, this presumed forest recovery could be due to forest plantations of non-native species with extraction purposes. It is estimated that Vichada has 569653 ha suitable for commercial forest plantations, located mainly in the municipalities of Cumaribo, La Primavera and Puerto Carreño (near the Bita's river basin). In these places, plantations started in 2006 through carbon credits commercialization. These plantations were prioritized after the creation of these programs: the Forest Incentive Certificate (CIF) (implemented by the law 1337), the "Action Plan for Commercial Reforestation" in 2011 (MADR, 2011), and the "CONPES 3797" strategy (CONPES, 2014). Altogether, these policies supported more than $70 \%$ of the investments made in forest plantations in Vichada (Gómez, 2015).

Another factor that contributes to the deforestation in the Bita's river basin is the livestock production. The economy of La Primavera municipality (where part of the Bita's river is located) is based on extensive livestock farming, with a disproportionate land-use for this activity that covers $90 \%$ of the territory (Álvarez, 2016). After major technological advances, and the Laws 135 of 1961 and 30 of 1988, the livestock farming frontier was enlarged covering the forested areas of Vichada (Gómez, 2015). During the evaluated period in this study (1985-2017), an increase of more than $100 \%$ in the pasture cover was proposed in the "Strategic Plan of Colombian Livestock Farming". The purpose of this policy was the introduction of improved African pastures, mainly of the genus Brachiaria, and burn natural savannas (Arias, 2004; Andrade-Pérez et al., 2013; Fedegan, 2021). This is shown in Table 4 , noticing the increase in savannas, because it is not possible to distinguish endemic savannas from introduced pastures. In addition to deforestation, pastures without proper management can increase soil degradation, destroying native fauna and flora (Trillos, 2010).

On the other hand, population growth in poorly occupied territories, as is the case of Vichada, produces drastic land-use changes, not only due to agricultural expansion, but also because of communication and trade routes construction (Perz et al., 2005). Since the dynamics of landscape transformation can be accelerated by rapid population growth, the increase of urban area (infrastructure) in the Bita's river basin is noteworthy (Table 4). Also, an increase of $34 \%$ in the population between 1980 and 2000, and $70 \%$ between 2001-2017, is directly related to the social and economic opportunities provided by agribusiness (DANE, 2015). Moreover, roadway constructions such as the highway between the municipalities of Puerto Carreño and Puerto Gaitán (department of Meta), that promotes the economic development of the Altillanura, and the mega-road project that will connect Colombia and Venezuela with a total length of $2661 \mathrm{~km}$, represent additional threats for the Bita river basin (DNP, 2018).

Table 4. Area and percentages of land-covers from 1985 to 2017 in the Bita river basin.

\begin{tabular}{ccccccc}
\hline & \multicolumn{2}{c}{1985} & \multicolumn{2}{c}{2001} & \multicolumn{2}{c}{2017} \\
Land-cover class & ha & $\%$ & ha & $\%$ & ha & $\%$ \\
Forest & 347994 & $42.84 \%$ & 88704 & $11.86 \%$ & 135656 & $16.70 \%$ \\
Savannas & 315339 & $38.82 \%$ & 376327 & $3.08 \%$ & 477639 & $58.80 \%$ \\
Soil/Scattered vegetation & 38097 & $4.69 \%$ & 162608 & $2.61 \%$ & 28349 & $3.49 \%$ \\
Cropland & 93497 & $11.51 \%$ & 165350 & $0.28 \%$ & 151090 & $18.60 \%$ \\
Water & 16327 & $2.01 \%$ & 16327 & $8.59 \%$ & 16327 & $2.01 \%$ \\
Infrastructure & 1056 & $0.13 \%$ & 2994 & $4.70 \%$ & 3249 & $0.40 \%$
\end{tabular}


Table 5. Classified images validation and percentages of user's accuracy and producer's accuracy. Where g.a. means general accuracy and k.i. means Kappa index.

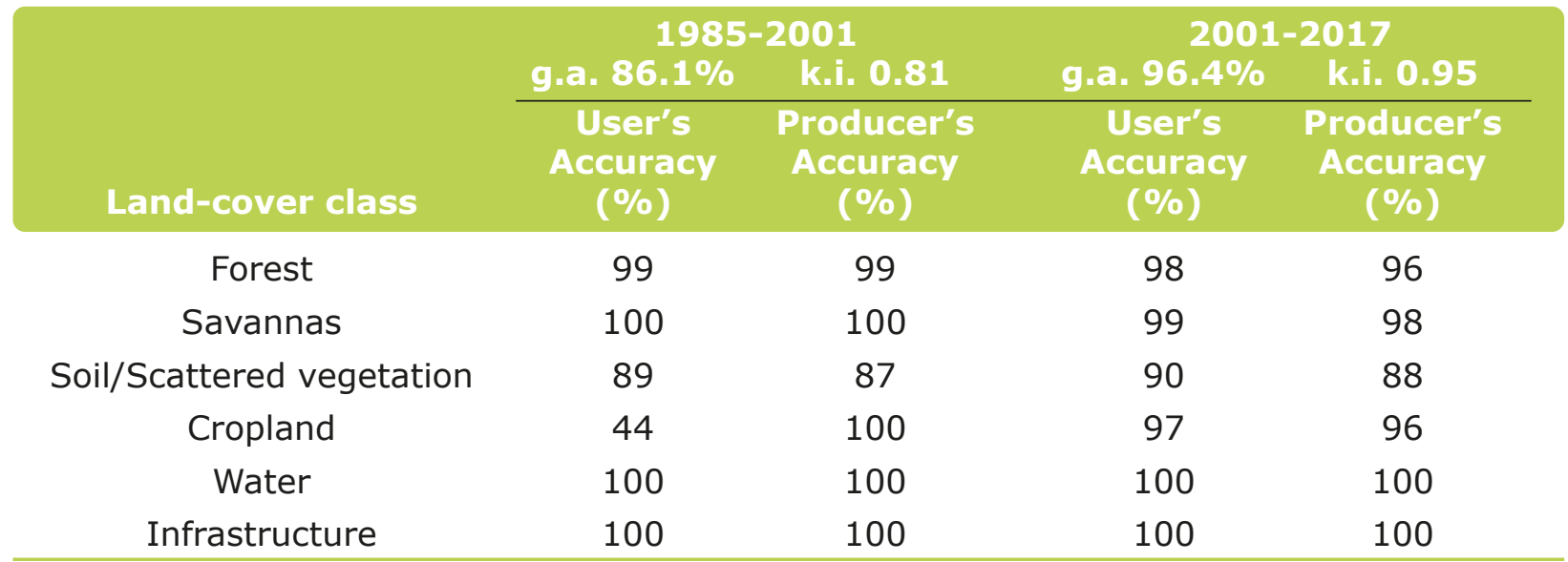

Source: Authors.

Table 5 shows validation of the image classification process for the evaluated periods, through a cross-tabulation matrix containing the Kappa index, general accuracy, user's accuracy and producer's accuracy, finally, indicating a statistical validation above $85 \%$ for the MLC both periods. Considering this, the maps in Fig. 6 (see Annex) were constructed. These maps provide a comparison of the land-cover classes distribution in the selected periods (1985-2001 and 2001-2017). A transition from forests to savannas, pastures (scattered vegetation) and croplands, especially during the $1985-2001$ period, as well as a replacement of natural savannas for pastures (scattered vegetation), croplands and bare soil during the same period is shown. In the 2001-2017 period, a change from bare soil/scattered vegetation to savannas and pastures was observed too.

The management of basins should tend to maintain mature and productive forest areas, as well as to decrease tensors (Sánchez et al., 2015). Therefore, maintaining the forest cover is important to preserve the current state of conservation in the Bita's river basin. This is especially relevant since the wetland can provide ecological balance to endure the high pressure of climate change in the region, where the dry season is particularly strong, due to the high evaporation rates and the runoff, and to avoid future problems due to water demand (CIAT \& Cormacarena, 2017; Yepes-Mayorga, 2012).

Although the Bita's river currently has a protection figure, since it was included in the Ramsar list of wetlands of international importance (Decree 1235, 2018), this type of protection does not have a management plan with defined zones. Thus, environmental authorities cannot exercise control over the territory. The promptness of the land-use transformations makes current environmental regulations and laws useless. Hence, the biodiversity at the river basin is exposed to the effects of the agricultural frontier expansion (CIAT \& Cormacarena, 2017). Moreover, the Ramsar convention is mainly based on migratory bird activities, which leaves out a great part of the biodiversity that this basin encompasses (Ramsar, 2015). Therefore, despite the existence of a protection figure in the Bita river, a greater knowledge of the ecosystems and a well-designed management plan oriented towards environmental recovery is needed for this area.

Finally, the inadequate use of land is partially caused by the lack of environmental awareness in the local communities. Another important aspect is that environmental government entities have not made enough efforts to investigate the territory. Currently, there is little to non- existent information regarding the biodiversity of this area, since there is only one real scientific research available (Trujillo \& Lasso, 2017). This is why the present research seeks to provide information that encourages others to do investigations in the area, so they can contribute to the conservation and sustainability of important ecosystems of Vichada. 


\section{CONCLUSIONS}

The present study monitored the landcover changes in Vichada (Colombia) within a 32-year period. As a result, were obtained classified maps of the years 1985-2017, using satellite images and information regarding agribusiness. It was identified that the landcover change, and land-use change in Vichada reflects several processes at different scales, such as an initial use of land for subsistence farming, a population growth that responded to national development policies, changes in the regional economy mainly due to extensive livestock farming, and finally, large-scale agro-industrial projects that resulted from national stimulus. Therefore, both, policies and economic practices, promote changes in the forest cover. The results showed a transition from forests to other land-cover classes, such as croplands and pastures. A great loss of forest cover was noted, about 60 $\%$ during the last 32 years. Hence, the effects of deforestation on these natural ecosystems should be from now on a matter of research.

\section{AUTOR CONTRIBUTIONS}

Juan J. Vitar-Mendoza and Karen $X$. Sandoval-Parra mapped the land cover for both study areas, consulted agribusiness data, performed all the analysis for the land cover change, wrote the preliminary manuscript, and executed further edition and revision. Martha L. Ortiz-Moreno was responsible for the conceptual design of the study and contributed significantly to improve the manuscript. All authors jointly contributed to the submitted version of the manuscript.

\section{ACKNOWLEDGEMENTS}

The authors would like to thank the University of the Llanos for providing the ArcGIS 10.6 software, and the United States Geological Survey (USGS) for the satellite images. We would also like to express our gratitude to Yulieth Navarro-Herrera for her assistance in the initial phase of this study.

\section{REFERENCES}

Addabbo, P., Focareta, M., Marcuccio, S., Votto, C. \& Ullo, S. L. (2016). Contribution of Sentinel-2 data for applications in vegetation
The Bita's river basin should become a priority area for conservation since it is currently affected by anthropogenic stressors (that reduced its forested area to one-third) and is vital for water availability. Moreover, it was found that a great part of the intervention in this area is located nearby Puerto Carreño municipality, which raises a challenge for ecological conservation because it is there where a great part of the biodiversity is concentrated. In addition to the need for more research, is fundamental more attention to the development of policies for resources management. The lack of regulation from environmental authorities is a relevant issue as well. Also, in this context, it should be mentioned that to resolve conflicts of landuse in Vichada, land ownership of local communities must be clarified, considering their needs and the preservation of natural resources. Lastly, despite its limitations, this study provides useful findings for territory planning and decision-making.

monitoring. Acta IMEKO, 5(2), 44-54, http:// dx.doi.org/10.21014/acta_imeko.v5i2.352

Aide, M., Clarck, M., Grau, R., López-Carr, D., Levy, M. A., Redo, D., Bonilla-Moheno, M., George, M., Andrade-Núñez, M. M. (2013). Deforestation and reforestation of Latin America and the Caribbean (2001 - 2010). Biotropica. 45(2), 262-271, https://doi. org/10.1111/j.1744-7429.2012.00908.x

Allan, E., Manning, P., Alt, F., Binkenstein, J., Blaser, S., Blüthgen, N., Böhm, S., Grassein, F., Hölzel, N., Klaus, V. H., Kleinebecker, T., Morris, E. K., Oelmann, Y., Prati, D., Renner, S. C., Rillig, M. C., Schaefer, M., Schloter, M., Schmitt, B... Fischer (2015). Land use intensification alters ecosystem multifunctionality via loss of biodiversity and changes to functional composition. Ecology Letters, 18(8), 834-843, https://doi. org/10.1111/ele.12469

Álvarez, S. (2016). Mecanismo para la gestión de la difusión de sistemas silvopastoriles en el municipio de La Primavera Vichada [Tesis de Especialización 
en Administración de Agronegocios]. [Bogotá D.C.]: Universidad de la Salle.

Álvarez, J. \& Agredo, G. (2013). Pérdida de la cobertura vegetal y de oxígeno en la media montaña del trópico andino, caso cuenca urbana San Luis (Manizales). Luna Azul, (37), 30-48. ISSN: 1909-2474.

Andrade-Pérez, G.I., Romero, M. \& Delgado, J. (2013). Diseño adaptativo de un paisaje agroindustrial. Una propuesta para la transformación agrícola de la altillanura colombiana. Ambiente y Desarrollo, 17(33), 29-41.

Arias, J. (2004). Ganadería, paisaje, territorio y región: una historia ecológica y social de la Orinoquia colombiana. Bogotá D.C., Colombia: Instituto de Investigación de Recursos Biológicos Alexander von Humboldt.

Ávalos, A., Flores, F., Nájera, O. \& Marceleño, S. M. L. (2018). Analysis of the land use and cover changes in the metropolitan area of Tepic-Xalisco (1973-2015) through landsat images. Sustainability, 10(6), 1860. https://doi.org/10.3390/su10061860

Barragán, I. D. (2018) Análisis multitemporal del cauce del río Magdalena en el periodo 2016-2018 en el sector de Puerto Salgar - La Dorada a través de análisis de imágenes radar. [Tesis de Especialización en Geomática]. [Bogotá D.C.]: Universidad Militar Nueva Granada.

Beisel, N. S., Callaham, J. B., Sng, N. J., Taylor, D. J., Paul, A. L. \& Ferl, R. J. (2018). Utilization of single-image normalized difference vegetation index (SI-NDVI) for early plant stress detection. Applications in plant sciences, 6(10), https://doi. org/10.1002/aps3.1186

Benstead, J.P. \& Pringle, C.M. (2004). Deforestation alters the resource base and biomass of endemic stream insects in eastern Madagascar. Freshwater Biology, 49, 490-501. https://doi.org/10.1111/j.13652427.2004.01203.x

Bolstad, P. \& Lillesand, T.M. (1991) Rapid maximum likelihood classification. Photogrammetric Engineering \& Remote
Sensing, 571, 67-74.

Borras Jr, S.M., Kay, C., Gómez, S. \& Wilkinson, J. (2012). Land grabbing and global capitalist accumulation: key features in Latin America. Canadian Journal of Development Studies, 33(4), 402-416. https://doi.org/10 $.1080 / 02255189.2012 .745394$

Boserup, E. (2017). The conditions of agricultural growth: The economics of agrarian change under population pressure. New York: Routledge. https://doi. org/10.4324/9781315070360

Bradshaw, C., Sodhi, N. \& Brook, B. (2008). Tropical turmoil: a biodiversity tragedy in progress. Frontiers in Ecology and the Environment, 7, 79-87. https://doi. org/10.1890/070193

Brodie, J. F., Giordano, A. J., Dickson, B., Hebblewhite, M., Bernard, H., Mohd-Azlan, J., Andersson, J., Ambu, L. (2015). Evaluating multispecies landscape connectivity in a threatened tropical mammal community. Conservation Biology, 29(1), 122-132. https://doi.org/10.1111/cobi.12337

Caicedo, G. (2016). Perspectivas del desarrollo regional local para la Orinoquia. Orinoquia, 20(1), 7-9, ISSN 0121-3709.

Castiblanco, C., Etter, A. \& Aide, T. M. (2013) Oil palm plantations in Colombia: a model of future expansion. Environmental Science \& Policy, 27(1), 72-83, https://doi. org/10.1016/j.envsci.2013.01.003

Caviedes, J. \& Ibarra, J. T. (2017). Influence of anthropogenic disturbances on stand structural complexity in Andean temperate forests: implications for managing key habitat for biodiversity. PloS one, 12 (1., https://doi.org/10.1371/journal. pone. 0169450

CGR-Office of Comptroller General of the Republic. (2012). Ministerio de Agricultura y Desarrollo Rural Plan Agro 2003-2015 para la Agricultura y la Vida Rural de las Americas (periodo 2003 - 2011). October 2012, Bogotá D.C., Colombia. [Retrieved from: https://www.contraloria.gov.co/ documents/20181/463150/8311317402_ 
Informe Auditoria Plan 2003-2015 MADR.pdf/df1a66f4-d30b-4dfb-a44ce79c54a4e1f3?version $=1.0]$

CGR-Office of Comptroller General of the Republic. (2014) Informe de actuación especial (ACES) Instituto Colombiano de Desarrollo Rural-Incoder "Actuación especial sobre la acumulación irregular de predios baldíos en la Altillanura Colombiana". Bogotá D.C., Colombia. [Retrieved from: http:// www.observatoriodetierras.org/wp-content/ uploads/2014/04/Contralor\% C3\%ADaGeneral-de-la-Rep\%C3\%BAblica.-INCODERAcumulacion-Irregular-de-Baldios-InformeACES.pdf]

Chakraborty, A., Seshasai, M. V. R., Reddy, C. S. \& Dadhwal, V. K. (2018). Persistent negative changes in seasonal greenness over different forest types of India using MODIS time series NDVI data (2001-2014). Ecological Indicators, 85, 887-903. https:// doi.org/10.1016/j.ecolind.2017.11.032

CIAT (International Center for Tropical Agriculture) \& CORMACARENA (Corporation for the Sustainable Development of La Macarena Special Management Area). (2017) Plan Regional Integral de Cambio Climático para la Orinoquia. CIAT: publication No. 438, Libre Expresión Creativos SAS: Cali, Colombia, pp. 51-133.

CONPES 3192. (2002). Plan Colombia: Alternativas energéticas en el Pacífico, la Orinoquia y la Amazonía. Bogotá DC, Colombia: Office of National Department of Planning.

CONPES 3218. (2003). Programa de desarrollo alternativo 2003 - 2006. Bogotá DC, Colombia: Office of National Department of Planning.

CONPES 3467. (2007). Concepto favorable a la nación para contratar un empréstito externo con la banca multilateral por un valor de hasta US \$30 millones o su equivalente en otras monedas, para financiar parcialmente el proyecto "Apoyo a alianzas productivas fase II". Bogotá DC, Colombia: Office of National Department of Planning.

CONPES 3558. (2008). Estrategias para fortalecer las convocatorias para el desarrollo rural. Bogotá DC, Colombia: Office of National Department of Planning.

CONPES 3669. (2010). Política nacional de erradicación manual de cultivos ilícitos y desarrollo alternativo para la consolidación territorial. Bogotá DC, Colombia: Office of National Department of Planning.

CONPES 3797. (2014). Política para el desarrollo integral de la Orinoquia: Altillanura-Fase I. Bogotá DC, Colombia: Office of National Department of Planning.

CONPES 3827. (2015). Distribución de recursos para el certificado de incentivo forestal con fines comerciales (CIF de reforestación), vigencia 2015. Bogotá DC, Colombia: Office of National Department of Planning.

CORPORINOQUIA (Orinoquía Regional Autonomous Corporation). (2009). Resolution 200.41-09-1592. Tramite tendiente a otorgar licencias ambientales, concesiones, permisos y autorizaciones requeridas por la ley para el uso, aprovechamiento o movilización de los recursos naturales renovables o para el desarrollo de actividades que afecten o puedan afectar el medio ambiente en la jurisdicción de CORPORINOQUÍA. [Retrieved from: http://www.corporinoquia.gov.co/files/ Gestion_tramites_y_servicios_ambientales/ Resolucin_200_41_09-1592_LICENCIAS_ AMBIENTALES_CONSECIONES_PERMISOS_ AUTORIZACIONES.pdf]

CORPORINOQUIA (Orinoquia Regional Autonomous Corporation). (2013a). Plan de Gestión Ambiental Regional 2013-2025. [Retieved from: https://www.corporinoquia. gov.co/files/pgar/doc_final_\%20 PGAR_2013_2025.pdf]

CORPORINOQUIA (Orinoquía Regional Autonomous Corporation). (2013b). Resolution 500.41-13-1571. Criterios regionales para el desarrollo de proyectos forestales, agrícolas y agroindustriales en la jurisdicción de CORPORINOQUÍA. [Retrieved from: http://www.corporinoquia.gov.co/files/ Gestion_tramites_y_servicios_ambientales/ Resolucin_50041131571.pdf] 
DANE (National Administrative Department of Statistics). (1985). Censo General 1985- Estimaciones de población 1985-1992 [Retrieved from: https://www. dane.gov.co/index.php/estadisticas-portema/demografia-y-poblacion/muestrascensales].

DANE (National Administrative Department of Statistics). (1993). Censo General 1993- Estimaciones de población 1993-2004 [Retrieved from: https://www. dane.gov.co/index.php/estadisticas-portema/demografia-y-poblacion/muestrascensales].

DANE (National Administrative Department of Statistics). (2005). Censo General 2005- Estimaciones de población 2005-2020 [Retrieved from: https://www. dane.gov.co/index.php/estadisticas-portema/demografia-y-poblacion/muestrascensales].

Dávalos, L.M., Holmes, J.S., Rodríguez, N.. \& Armenteras, D. (2014). Demand for beef is unrelated to pasture expansion in Northwestern Amazonia. Biological Conservation, 170, 64-73 https://doi. org/10.1016/j.biocon.2013.12.018

Dayrell, C. (2012). El Cerrado brasilero: Sabanas bajo presión. De la euforia al desastre. El caso de los Cerrados en el Norte de Minas Gerais. https://www.semillas.org. co/es/de-la-euforia-al-desastre

Decree 1235. Office of Ministry of Environment and Sustainable Development, Bogotá DC, Colombia, July 18th, 2018.

Decree 1541. Office of Ministry of Agriculture, Bogotá DC, Colombia, July 26th, 1978.

Decree 1640. Office of Ministry of Environment and Sustainable Development, Bogotá DC, Colombia, August 2nd, 2012.

Decree 1729. Presidency of the Republic, Bogotá DC, Colombia, August 6th, 2002.

Decree 2858. Presidency of the Republic, Bogotá DC, Colombia, October 13rd, 1981.

Decree 3100. Office of Ministry of Environment and Sustainable Development, Bogotá DC, Colombia, October 30th, 2003.

DNP-Office of National Department of
Planning. (2017) Regionalización: Presupuesto de inversión vigencia 2017, versión preliminar e indicativa. Bogotá DC, Colombia. [Retrieved from: https://colaboracion.dnp.gov.co/CDT/ Inversiones $\% 20 y \% 20$ finanzas $\% 20$ pblicas/ LibroRegPreInd-POAI2017.pdf]

DNP-Office of National Department of Planning. (2018). Perspectivas del Plan Nacional de Desarrollo frente a los procesos de ordenamiento territorial. Regional PND 2018-2022: Pacto por Colombia, pacto por la equidad. Bogotá DC, Colombia.

Dominati, E., Patterson, M. \& Mackay, A. (2010). A framework for classifying and quantifying the natural capital and ecosystem services of soils. Ecological Economics, 69(9), 1858-1868. https://doi.org/10.1016/j. ecolecon.2010.05.002

Duarte, C. (2016). Desencuentros territoriales. Tomo II. el caso de la Altillanura. Caracterización de los conflictos en las regiones de la Altillanura, Putumayo y Montes de María. Bogotá D.C., Colombia: Instituto Colombiano de Antropología e Historia.

Dudley, N. \& Alexander, S. (2017). Agriculture and biodiversity: a review. Biodiversity, 18, 45-9. https://doi.org/10.10 80/14888386.2017.1351892

Etter, A., McAlpine, C., Pullar, D. \& Possingham, H. (2005). Modeling the age of tropical moist forest fragments in heavily-cleared lowland landscapes of Colombia. Forest Ecology and Management, 208, 249-260. https://doi.org/10.1016/j. foreco.2004.12.008

Etter, A., McAlpine, C. \& Possingham, H. (2008). Historical patterns and drivers of landscape change in Colombia since 1500: a regionalized spatial approach. Annals of the American Association of Geographers, 98(1), 2-23.

Federación Colombiana de Ganaderos Fedegan. (2021). Inventario Nacional Bovino a Nivel Municipal. Bogotá D.C., Colombia: Federación Colombiana de Ganaderos [Retrieved from: https://www.fedegan.org. co/estadisticas/inventario-ganadero] 
Ferraz, K. M. P. M. B., Siqueira, M. F., Martin, P.S., Esteves, C. F. \& Couto, H. T. Z. (2010). Assessment of Cerdocyon thous distribution in an agricultural mosaic, southeastern Brazil. Mammalia, 74, 275-280. http://dx.doi.org/10.1515/MAMM.2010.036

Fröhlich, B., Bach, E., Walde, I., Hese, S., Schmullius, C. \& Denzler, J. (2013). Land cover classification of satellite images using contextual information. ISPRS Annals of the Photogrammetry, Remote Sensing and Spatial Information Sciences, Volume II-3/ W1. VCM 2013 - The ISPRS Workshop on 3D Virtual City Modeling, 28 May 2013, Regina, Canada.

Gassón, R. A. (2002). Orinoquia: The archaeology of the Orinoco River Basin. Journal of World Prehistory, 16(3), 237-311, https://doi.org/10.1023/A:1020978518142

Gómez, P. (2015) Vichada: Acaparamiento de tierras en la última frontera agraria. [Tesis de Maestría en Geografía]. [Bogotá D.C., Colombia]: Universidad de los Andes

Gómez, S. \& Soto, F. (2012). Dinámicas del mercado de tierra en América Latina. Rome: Food and Agriculture Organization of the United Nations (FAO), ISBN 978-92-53071117.

Grande, J.D. (2015) Modelamiento morfométrico y análisis multitemporal del uso del suelo y cobertura vegetal de la subcuenca del río Molino ubicada en el municipio de Popayán, departamento del Cauca, Utilizando la metodología Corine Land Cover con imágenes de sensores remotos. [Tesis de Especialización en Sistemas de Información Geográfica]. [Manizales]: Universidad de Manizales.

Hernández, L.N. \& Salamanca, J.A. (2019) Análisis multitemporal del cambio de cobertura vegetal y su influencia en la generación de caudales pico de la cuenca Sardinata, del departamento de Norte de Santander-Colombia. [Tesis de Especialización en Recursos Hídricos]. [Bogotá D.C.]: Universidad Católica de Colombia.

Hoffmann, C. García, J. R. \& Krueger, T. (2018). A local perspective on drivers and measures to slow deforestation in the Andean-Amazonian foothills of Colombia. Land use policy, 77, 379-391. https://doi. org/10.1016/j.landusepol.2018.04.043

Hurd, L. E., Sousa, R. G., Siqueira-Souza, F. K., Cooper, G. J., Kahn, J. R. \& Freitas, C. E. (2016). Amazon floodplain fish communities: habitat connectivity and conservation in a rapidly deteriorating environment. Biological Conservation, 195, 118-127, https://doi. org/10.1016/j.biocon.2016.01.005

Institute of Hidrology, Metereology and Environmental Studies- IDEAM. (2010) Leyenda nacional de coberturas de la tierra. Metodología CORINE Land Cover adaptada para Colombia Escala 1:100.000. IDEAM: Bogotá DC, Colombia, pp. 9-67.

Jantz, S. M., Barker, B., Brooks, T. M., Chini, L. P., Huang, Q., Moore, R. M., Noel, J., Hurtt, G. (2015). Future habitat loss and extinctions driven by land-use change in biodiversity hotspots under four scenarios of climate-change mitigation. Conservation Biology, 29(4), 1122-1131, https://doi. org/10.1111/cobi. 12549

Khan, M. M. H., Bryceson, I., Korine N., Kolivras, K. N., Faruque, F. , Rahman, M. M. \& Haque, U. (2014). Natural disasters and land-use/land-cover change in the southwest coastal areas of Bangladesh. Regional Environmental Change, 15, 241-250. https:// doi.org/10.1007/s10113-014-0642-8

Keshtkar, H., Voigt, W. \& Alizadeh, E. (2017). Land-cover classification and analysis of change using machine-learning classifiers and multi-temporal remote sensing imagery. Arabian Journal of Geosciences, 10(154). https://doi.org/10.1007/s12517-017-2899-y

Lasso, C. A., Rial, A., Colonnello, G., Machado-Allison, A. \& Trujillo, F. (2014). $X I$. Humedales de la Orinoquia (ColombiaVenezuela). Bogotá DC, Colombia: Serie Editorial Recursos Hidrobiológicos y Pesqueros Continentales de Colombia, Instituto de Investigación de Recursos Biológicos Alexander von Humboldt (IAvH).

Law 30. Congreso de la República. Bogotá D.C., Colombia, March 18th 1988, [Retrieved 
from: http://www.suin-juriscol.gov.co/ viewDocument.asp?ruta=Leyes/1787345]

Law 135. Congreso de la República. Bogotá D.C., Colombia, December 15th 1961, [Retrieved from: https://www. funcionpublica.gov.co/eva/gestornormativo/ norma.php?i=74153]

Law 160. Congreso de la República. Bogotá D.C., Colombia, August 3rd 1994, [Retrieved from: https://www.minagricultura.gov.co/ Normatividad/Leyes/Ley\%20160\%20de\%20 1994.pdf]

Law 1337. Congreso de la República. Bogotá D.C., Colombia, January 8th 2010, [Retrieved from: http://www.suin-juriscol. gov.co/viewDocument. asp?id=1677696]

Law 1776. Congreso de la República. Bogotá D.C., Colombia, January 29th 2016, [Retrieved from: https://dapre.presidencia. gov.co/normativa/normativa/LEY\% 20 1776\%20DEL\%2029\%20DE\%20ENERO\%20 DE\%202016.pdf]

MADR - Office of Ministry of Agriculture and Rural Development. (2004) El renacimiento de la Orinoquia alta de Colombia. Bogotá DC, Colombia [Retrieved from: https://repository. agrosavia.co/handle/20.500.12324/18893]

MADR - Office of Ministry of Agriculture and Rural Development. (2011) Plan de Acción para la Reforestación Comercial. Bogotá DC, Colombia. [Retrieved from: https://vuf.minagricultura.gov. co/Documents/5. $\% 20$ Estadisticas $\% 20$ Sector $\% 20$ Forestal/PIan $\% 20$ de $\% 20$ Accion\%20Reforestacion\%20Comercial.pdf]

Maldonado-Ocampo, J. A., Vari, R. P. \& Usma, J. S. (2008). Checklist of the freshwater fishes of Colombia. Biota colombiana, 9(2), 143-237. https://www.redalyc.org/articulo. oa?id=49120960001

Mejía-Ramírez, J.A. (2016) Análisis multitemporal utilizando técnicas de Teledetección de la pérdida de cobertura vegetal por causa de la minería ilegal en el Bajo Cauca Antioqueño. [Tesis de Especialización en Geomática]. [Bogotá D.C.]: Universidad Militar Nueva Granada.
Mendoza, M. E., Granados, E. L., Geneletti, D., Pérez-Salicrup, D. R. \& Salinas, V. (2011). Analysing land cover and land use change processes at watershed level: a multitemporal study in the Lake Cuitzeo Watershed, Mexico (1975-2003). Applied Geography, 31(1), 237-250, https://doi. org/10.1016/j.apgeog.2010.05.010

Minjusticia - Office of Ministry of Justice and Law. (2014) Caracterización Regional de la problemática asociada a las drogas ilícitas en el departamento de Vichada, Bogotá DC, Colombia, pp. 32-48, [Retrieved from: http:// www.odc.gov.co].

Modica, G., Pollino, M. \& Solano, F. (2019) Sentinel-2 imagery for mapping mork oak (Quercus suber L.) distribution in Calabria (Italy): Capabilities and quantitative estimation. In New Metropolitan Perspectives, eds. Calabrò, F., Della Spina, L., Bevilacqua, C. ISHT 2018, Smart Innovation, Systems and Technologies, vol. 100. Springer, Cham, https://doi.org/10.1007/978-3-319-920993_8

Monroy, D.M. \& Armenteras, D. (2017). Land cover change caused by alluvial mining on the Nechí river, Antioquia (Colombia). Gestión y Ambiente, 20(1), 50-61. http:// dx.doi.org/10.15446/ga.v20n1.61513

Munsi, M., Malaviya, S., Oinam, G. \& Joshi, PK. (2010). A landscape approach for quantifying land-use and land-cover change (1976-2006) in middle Himalaya. Regional Environmental Change, 10(2), 145-155. https://doi.org/10.1007/s10113-009-0101-0

Muñoz, D., Rodríguez, M. \& Romero, M. (2009). Análisis multitemporal de cambios de uso del suelo y coberturas, en la microcuenca Las Minas, corregimiento de La Laguna, municipio de Pasto, departamento de Nariño. Revista de Ciencias Agrícolas, 26(1), 11-24.

Nawar, S., Buddenbaum, H., Hill, J. \& Kozak, J. (2014). Modeling and mapping of soil salinity with reflectance spectroscopy and Landsat data using two quantitative methods (PLSR and MARS). Remote Sensing, 6(11), 10813-10834. https://doi.org/10.3390/ rs61110813 
Newbold, T., Hudson, L. N., Hill, S. L., Contu, S., Lysenko, I., Senior, R. A., Börger, L., Bennet, D. J., Choimes, A., Collen, B., Day, J., De Palma, A., Díaz, S., EcheverríaLondoño, S., Edgar, M. J., Feldman, A., Garon, M., Harrison, M. L. K., Alhusseine, T... Purvis, A. (2015). Global effects of land use on local terrestrial biodiversity. Nature, 520(7545), 45-50. https://doi.org/10.1038/nature14324

Nieto, L. E. (2015). Chapter 4: La Orinoquia Colombiana y el Biodiesel. In Biotecnología, Agrocombustibles y cambio climático. In Biotecnología, Agrocombustibles y cambio climático. Perspectiva crítica, ed. L. E. Nieto (Universidad Nacional Abierta y a Distancia), 77-89

Ortega, L.M. (2016). Extranjerización de la tierra en la Altillanura Colombiana, durante el periodo 2002-2015. [Tesis del pregrado en Ciencias Políticas]. [Bogotá D.C.]: Pontificia Universidad Javeriana.

Oxfam. (2013). Divide y comprarás. Una nueva forma de concentrar tierras baldías en Colombia. Oxfam GB, Oxfam House, Jhon Smith Drive, Cowley, Oxford, UK: OXFAM International, $40 \mathrm{p}$.

Peña-Levano, L.M., Lowenberg-Deboer, J., Sanders, J., Preckel, P., Jerez, K. \& Fontanilla, C. (2018). Complementarity between production activities and resource use: Partial Budget Analysis vs. Linear Programming [poster]. [Washington DC]: Agricultural and Applied Economics Association Annual Meeting

Peñuela, L. \& Rodríguez, J.J. (2014). Chapter 1: Contexto forestal en la cuenca del río Bita, Vichada, in Manejo Forestal Sostenible en plantaciones en la cuenca del río Bita, Vichada, Colombia, eds. Pacheco, M., Peñuela, L., Solano, C., and Galán, S. [Bogotá D.C., Colombia: Asociación Red Colombiana de Reservas Naturales de la Sociedad Civil (RESNATUR), Fundación Natura (FN), World Wildlife Fund (WWF), The Nature Conservancy (TNC), and Parques Nacionales Naturales de Colombia (PNN)] 25-67

Perz, S.G., Aramburú, C. \& Bremner, J. (2005). Population, land use and deforestation in the pan amazon basin: a comparison of
Brazil, Bolivia, Colombia, Ecuador, Peru and Venezuela. Environment, Development and Sustainability, 7, 23-49. https://doi. org/10.1007/s10668-003-6977-9

Oficina del Alto Comisionado para la Paz Colombia (Office of the High Commissioner for Peace Colombia). (2016). Colombia: El Acuerdo Final de Paz. La oportunidad para construir paz (Cartilla completa del Acuerdo). June 2016. [Retrieved from: https://www. refworld.org.es/docid/5a874f254.html]

Príncipe, R. E. \& Willems, B. (2018). Aplicación del algoritmo de redes elásticas en imágenes satelitales. Revista de Investigación de Física, 21(1), 182101401.

Ramsar. (2015). Cuarto Plan Estratégico para 2016 - 2024. Punta del Este, Uruguay: Convención Relativa a los Humedales de Importancia Internacional Especialmente como Hábitat de Aves Acuáticas - la "Convención de Ramsar".

Ramsar. (2016). Introducción a la convención sobre los humedales. Manual de la Convención de Ramsar, Subserie I: Manual 1 Cooperación internacional sobre los humedales, 5th edition.

Rausch, J.M. (2017). Globalization and changing conceptions of Colombia's Llanos frontier since 1980. In Transnational frontiers of Asia and Latin America since 1800, eds. J. Moreno Tejada and B. Tatar. New York, USA: Routledge, Taylor and Francis group. 17-30 p.

Office of Ministry of Environment and Sustainable Development. (2004). Resolution 157. Uso sostenible, conservación y manejo de los humedales, y se desarrollan aspectos referidos a los mismos en aplicación de la Convención Ramsar. [Retrieved from: https:// www.cvc.gov.co/sites/default/files/Sistema Gestion_de_Calidad/Procesos $\% 20$ y $\% 20$ procedimientos $\% 20$ Vigente/Normatividad_ Gnl/Resolucion\%200196\%20de\%202006Feb-01.pdf]

Office of Ministry of Environment and Sustainable Development. (2006). Resolution 196. Guía técnica para la formulación de planes de manejo para humedales en Colombia. [Retrieved from: https://www. 
cvc.gov.co/sites/default/files/Sistema Gestion_de_Calidad/Procesos $\% 20 y \% 20$ procedimientos $\% 20$ Vigente/Normatividad_ Gnl/Resolucion\%200196\%20de\%202006Feb-01.pdf]

Office of Ministry of Environment and Sustainable Development. (2006). Resolution 1128. Guía técnica para la formulación de planes de manejo para humedales en Colombia. [Retrieved from: https://www. cvc.gov.co/sites/default/files/Sistema Gestion_de_Calidad/Procesos $\% 20 y \% 2 \overline{0}$ procedimientos $\% 20$ Vigente/Normatividad_ Gnl/Resolucion\%201128\%20de\%202006Jun-15.pdf]

Robinson, K. (2018). Araneae biodiversity in the Ecuadorian Chocó: Impact of altitude and land use on spider diversity. [Bachelor's dissertation in Comparative Ecology and Conservation]. [Minnesota]: University of Minnesota

Romero, M., Maldonado-Ocampo, J. A., Bogotá, J. D., Usama, S., Umaña, A. M., Murillo, J., Restrepo, S., Álvarez, M., Palacios, M. T., Valbuena, S., Mejía, S. L., Aldana, J. Payán, E. (2009). Informe sobre el estado de la biodiversidad en Colombia 2007-2008: piedemonte orinoquense, sabanas y bosques asociados al norte del río Guaviare. Bogotá: Instituto de Investigación de Recursos Biológicos Alexander von Humboldt (IAvH).

Romero, M., Trujillo, F., Lasso, C.A. \& Campo, O. (2017). Chapter 1: Área de estudio. In IV. Biodiversidad en el río Bita, Vichada, Colombia, eds. F. Trujillo and C. A. Lasso (Editorial fauna Silvestre Neotropical). Bogotá DC: Instituto de Investigación de Recursos Biológicos Alexander von Humboldt (IAvH). 29-45 p.

Salamanca-Córdoba, N.L. (2020) Análisis multitemporal de las coberturas del uso del suelo en la microcuenca río Blanco de San José, municipio de Mogotes, Santander. [Tesis de Especialización en Ordenamiento y Gestión Integral de Cuencas Hidrográficas]. [Bogotá D.C.]: Universidad Santo Tomás.

Sanabria-Lombana, B.J. (2018) Análisis multitemporal de la cobertura vegetal, zonas de erosión y dirección del cauce, en la cuenca del río Cravo Sur, comprendido desde el municipio de Soacha en el departamento de Boyacá hasta el municipio de Yopal en el departamento de Casanare. [Tesis de pregrado en Ingeniería Geológica]. [Tunja]: Universidad Pedagógica y Tecnológica de Colombia.

Sánchez, D., Pinilla, G.A. \& Mancera, J.E. (2015). Effects of land use on soil properties and run-off in a Colombian Orinoco water basin. Colombia Forestal, 18(2), 255-272. https://doi.org/10.14483/udistrital.jour. colomb.for.2015.2.a06

Santacruz-Delgado, A.M. (2019). Recent and future anthropogenic transformation of the colombian llanos. [Doctorate's dissertation in Philosophy]. [Worcester, Massachusetts, USA]: Clark University

Sheng, H., Chen, X., Su, J., Rajagopal, R. \& Ng, A. (2020). Effective data fusion with Generalized Vegetation Index: Evidence from land cover segmentation in agriculture. Proceedings of the IEEE/CVF Conference on Computer Vision and Pattern Recognition (CVPR) Workshops, 2020, pp. 60-61.

Souza-Filho, P. W. M., Nascimento, W. R., Santos, D. C., Weber, E. J., Silva, R. O., \& Siqueira, J. O. (2018). A GEOBIA approach for multitemporal land-cover and land-use change analysis in a tropical watershed in the south-eastern Amazon. Remote Sensing, 10(11), 1683. https://doi.org/10.3390/ rs10111683

Suárez, C.F., Paez-Vasquez, M., Trujillo, F., Usma, J.S., Thieme, M., Bassi, A.M., Naranjo, L.G., Costanzo, S., Manrique, O., Pallaske, G. \& Flechas, J. (2021). How to protect free flowing rivers: The Bita river Ramsar Site as an example of science and management tools working together. Sustainability, 13, 1775. https://doi.org/10.3390/su13041775

Sun, Y., Ren, H., Zhang, T., Zhang, C. \& Qin, Q. (2018). Crop leaf area index retrieval based on inverted difference vegetation index and NDVI. IEEE Geoscience and Remote Sensing Letters, 15(11), 1662-1666. https:// doi.org/10.1109/LGRS.2018.2856765

Thompson, P. L., Rayfield, B. \& Gonzalez, 
A. (2017). Loss of habitat and connectivity erodes species diversity, ecosystem functioning, and stability in metacommunity networks. Ecography, 40(1), 98-108. https:// doi.org/10.1111/ecog.02558

Trillos G., D. (2010). Alternativas para aumentar la productividad en el sistema de explotación bovina extensiva de cría en el municipio de La Primavera, departamento del Vichada. [Tesis de Maestría en Desarrollo Rural]. [Bogotá D.C., Colombia]: Pontificia Universidad Javeriana

Trujillo, F. \& Lasso, C.A. (2017). IV. Biodiversidad en el río Bita, Vichada, Colombia. Bogotá D.C., Colombia: Editorial fauna Silvestre Neotropical, Instituto de Investigación de Recursos Biológicos Alexander von Humboldt.

USGS. (1985a). LT05_L1TP_004056_198 50310_20170219_01_T1, [satelital image], cited: 18 jun 2021 https://earthexplorer. usgs.gov/

USGS. (1985b). LT05_L1GS_005056_19 850301_20170219_01_T2, [satelital image], cited: 18 jun 2021. https://earthexplorer. usgs.gov/

USGS. (1998a). LT05_L1TP_005056_199 81202_20161220_01_T1, [satelital image], cited: 18 jun 2021. https://earthexplorer. usgs.gov/

USGS. (1998b). LT05_L1TP_004056_199 81125_20161220_01_T2, [satelital image], cited: 18 jun 2021. https://earthexplorer. usgs.gov/

USGS. (2001a). LE07_L1TP_004056_200 11125_20170202_01_T1, [satelital image], cited: 18 jun 2021. https://earthexplorer. usgs.gov/

USGS. (2001b). LE07_L1GT_005056_20 011031_20170202_01_T2, [satelital image], cited: 18 jun 2021. https://earthexplorer. usgs.gov/

USGS. (2005a). LE07_L1TP_004056_200 50120_20170116_01_T1, [satelital image]. [Retrieved from: https://earthexplorer.usgs. gov/, cited: 18 jun 2021.
USGS. (2005b). LE07_L1TP_005056_200 50127_20170117_01_T1, [satelital image], cited: 18 jun 2021. https://earthexplorer. usgs.gov/

USGS. (2009a). LE07_L1TP_004056_200 91201_20161216_01_T1, [satelital image], cited: 18 jun 2021. https://earthexplorer. usgs.gov/

USGS. (2009b). LE07_L1TP_005056_200 91122_20161217_01_T1, [satelital image], cited: 18 jun 2021. https://earthexplorer. usgs.gov/

USGS. (2013a). LE07_L1TP_004056_201 31126_20161119_01_T1, [satelital image], cited: 18 jun 2021. https://earthexplorer. usgs.gov/

USGS. (2013b). LE07_L1TP_005056_201 31117_20161119_01_T1, [satelital image], cited: 18 jun 2021. https://earthexplorer. usgs.gov/

USGS. (2017a). L1C_T19NFG_ $^{\text {[satelital }}$
A008616_20170214T145719,
image], cited: 18 jun 2021.
earthexplorer.usgs.gov/

USGS. (2017b). L1C_T19NEG_ A008616_20170214T145719, [satelital image], cited: 18 jun 2021. https:// earthexplorer.usgs.gov/

USGS. (2017c). L1C_T19NDG_ A008659_20170217T150714, [satelital image], cited: 18 jun 2021. https:// earthexplorer.usgs.gov/

USGS. (2017d). L1C_T19NCG A008659_20170217T150714, [satelital image], cited: 18 jun 2021. https:// earthexplorer.usgs.gov/

Vargas-González, J.A. (2013). Análisis multitemporal de la cobertura del suelo en el departamento del Huila (Alto Magdalena, Colombia). [Tesis de Pregrado en Ingeniería Geógrafa y AMbiental]. [Bogotá D.C.]: Universidad de Ciencias Aplicadas y Ambientales U.D.C.A.

Vargas, L. E. P., Laurance, W. F., Clements, 
G. R. \& Edwards, W. (2015). The impacts of oil palm agriculture on Colombia's biodiversity: what we know and still need to know. Tropical Conservation Science, 8(8), 28-45, https:// doi.org/10.1177/194008291500800317

Viloria, J. (2009). Geografía económica de la Orinoquia. Cartagena, Colombia: Banco de la República, Documentos de Trabajo sobre Economía Regional y Urbana, nº 113

Williams, B. A., Grantham, H. S., Watson, J., Alvarez, S. J., Simmonds, J., Rogéliz, C. et al. (2020) Minimizing the loss of biodiversity and ecosystem services in an intact landscape under risk of rapid agricultural development. Environmental Research Letters, 15, 014001 , https://doi.org/10.1088/1748-9326/ab5ff7

Yepes-Mayorga, A. (2012) Cambio Climático: estrategias de gestión con el tiempo en contra... Orinoquia, 16(1), 77-92.

Zuo, L., Zhang, Z., Zhao, X., Wang, X., Wu, W., Yi L. \& Liu, F. (2014). Multitemporal analysis of cropland transition in a climate sensitive area: a case of study of the arid and semiarid region of northwest China. Regional Environmental Change, 14, 75-89. https:// doi.org/10.1007\%2Fs10113-013-0435-5

\section{(c) (1) (2) (2)}

